\title{
Countering the Judicial Silencing of Critics: Article 2 TEU Values, Reverse Solange, and the Responsibilities of National Judges
}

\author{
Armin von Bogdandy* and Luke Dimitrios Spieker**
}

EU Rule of law crisis - Article 2 TEU - EU values - EU fundamental rights Freedom of speech - Member state courts - Interpretation of national law in conformity with Article 2 TEU values - Preliminary reference - Duty of referral - Criminal liability of judges - Reverse Solange - ASJP judgment Judicial applicability of Article 2 TEU - Value-oriented interpretation of EU law - Mutual Amplification - Essence of EU fundamental rights L.M. judgment - Aranyosi judgment - Federal balance - Red lines - Systemic deficiencies - Solange presumption - Mutual trust

\section{Problem, idea AND PRogramme}

The Polish government is stepping up its repression. Or so it seems. After packing the Constitutional Tribunal, dismissing more than 150 (out of 700) presidents and vice-presidents of ordinary courts, raising the overall number of Supreme

*Director, Max Planck Institute for Comparative Public Law and International Law, Heidelberg.

**Research Fellow and PhD Candidate, Max Planck Institute for Comparative Public Law and International Law, Heidelberg. The authors wish to thank the Dienstagsrunde, Piotr Bogdanowicz, Christoph Burchard, Iris Canor, Pedro Cruz Villalón, Lukas Huthmann, Michael Ioannidis and Nicole Lazzerini for valuable critique. This paper has been presented at the conference 'The EU Charter of Fundamental Rights in the Member States' (Mansfield College, Oxford, 22-23 March 2019). The first part draws on an earlier version published on Verfassungsblog.

European Constitutional Law Review, 15: 391-426, 2019

(C) 2019 The Authors. This is an Open Access article, distributed under the terms of the Creative Commons Attribution-NonCommercial-NoDerivatives licence (http://creativecommons.org/licenses/ by-nc-nd/4.0/), which permits non-commercial re-use, distribution, and reproduction in any medium, provided the original work is unaltered and is properly cited. The written permission of Cambridge University Press must be obtained for commercial re-use or in order to create a derivative work. doi: $10.1017 /$ S1574019619000324 
Court judges, and creating new tools for cowing judges, ${ }^{1}$ the Polish government now seems ready to instrumentalise this transformed judiciary. The freedom of political speech is a main target.

Possible evidence can be found in the proceedings against Wojciech Sadurski: for his vocal criticism of the current Polish government, ${ }^{2}$ Sadurski, a renowned law professor at the Universities of Sydney and Warsaw, is facing a range of legal proceedings. The governing Law and Justice Party (PiS) is suing Sadurski for civil defamation because he called it an 'organised criminal group'. In addition, the state-run public broadcaster (TVP) has pressed for defamation charges both under civil and criminal law, after Sadurski accused them of 'Goebbelsian' propaganda practices. ${ }^{3}$ Similarly, TVP filed a lawsuit against Polish Ombudsman Adam Bodnar as a private individual following a statement made shortly after the assassination of the mayor of Gdansk. Bodnar indicated that one motivation for the assassination could have been TVP's biased reports suggesting, inter alia, a connection of the mayor to Nazis and Communists and his involvement in corruption. Although the case was dismissed in first instance by the District Court of Warsaw, it has not been ruled out that TVP will appeal the case. ${ }^{4}$

The focus of this article is not to settle whether Bodnar's or Sadurski's statements are protected by free speech under Union law; for that, we do not have enough evidence. Rather, we will discuss novel responses of Union law to such a development and to illiberal tendencies more generally. These responses have one thing in common: they all aim to put Article $2 \mathrm{TEU}$ values into judicial practice. Under this premise, our argument will be divided into two parts. First, we identify what national

${ }^{1}$ On the measures, see European Commission, Proposal for a Council Decision on the determination of a clear risk of a serious breach by the Republic of Poland of the rule of law, COM/2017/ 0835 final; on the disciplinary regime for judges, see the recently triggered infringement procedure against Poland, European Commission, Rule of Law: European Commission launches infringement procedure to protect judges in Poland from political control, Press Release, 3 April 2019, available at 〈europa.eu/rapid/press-release_IP-19-1957_en.htm〉, visited 21 August 2019.

${ }^{2}$ For his views, see e.g. W. Sadurski, Poland's Constitutional Breakdown (Oxford University Press 2019); ibid., 'How Democracy Dies (in Poland): A Case Study of Anti-Constitutional Populist Backsliding', Sydney Law School Research Paper No. 18/01; ibid., 'Constitutional Crisis in Poland', in M.A. Graber et al. (eds.), Constitutional Democracy in Crisis (Oxford University Press 2018) p. 257; ibid., 'Polish Constitutional Tribunal Under PiS: From an Activist Court, to a Paralysed Tribunal, to a Governmental Enabler', 11 Hague Journal On The Rule Of Law (2018) p. 63.

${ }^{3}$ W. Sadurski, 'I criticized Poland's government. Now it's trying to ruin me', The Washington Post, 22 May 2019. In support of Sadurski, see G. de Búrca and J. Morijn, 'Open Letter in Support of Professor Wojciech Sadurski', Verfassungsblog, 6 May 2019.

${ }^{4}$ For a full account, see the Ombudsman's official website at (www.rpo.gov.pl/en/content/ information-about-lawsuit-filed-tvp-and-notified-chr-office), visited 21 August 2019. The case was dismissed in first instance by the Regional Court in Warsaw on 24 May 2019. In a press release issued immediately after the decision, TVP announced that it would appeal the case, see 〈centruminformacji.tvp.pl/42784780/oswiadczenie-telewizji-polskiej〉, visited 21 August 2019. 
judges can and must do when Article 2 TEU values are at stake (see infra under the heading 'Novel ways of protecting essential rights'). We expand the status quo in three respects: a duty to interpret and apply national law in conformity with Article 2 TEU values, a duty to refer such cases to the European Court of Justice, and possible criminal sanctions - under national law - for disrespecting Union values in domestic procedures. To some, these responses will seem far-reaching. We will, therefore, justify them in a second step within the framework of the Reverse Solange doctrine (see infra under the heading 'Legal framing via the Solange doctrine'). This doctrine provides the grounds for protecting Article 2 TEU values against unexpected challenges by authoritarian tendencies while maintaining the European federal balance. To this end, we recall the basics of the doctrine and show how the judicial applicability of Article 2 TEU can be construed. At the same time, this newly activated Article 2 TEU is both substantially restricted to the drawing of red lines and subject to a presumption of value compliance.

It should be stressed: we do not claim that this is the law as it stands or its only possible interpretation in light of the situation it faces. The task of legal scholarship, however, is not only to describe the law as it stands, or to criticise it, but also to show possible paths of legal development. This applies especially to situations of new and unprecedented challenges which allow a plethora of different responses. In this light, our proposals present one possible development of the law, one which is coherent with the path of European law, supported by relevant precedent, and covered by the legal mandate of the European Court of Justice in light of the challenges the Union is facing.

\section{NOVEL WAYS OF PROTECTING ESSENTIAL RIGHTS}

\section{Freedom of speech as an EU value}

Proceedings against critics like Bodnar and Sadurski are not an internal Polish but a European affair, as they affect the basic order of the European Union. They fall squarely into the situation addressed by the proposal of the European Commission for a decision under Article 7(1) TEU to determine 'a clear risk of a serious breach' of EU values. Though we cannot fully qualify the aforementioned cases, it seems likely that judicial proceedings against individuals expressing opinions - including offensive ones - on Polish public issues violate free speech under EU law. ${ }^{5}$

Of course, the EU Charter of Fundamental Rights protects the freedom of expression (Article 11 CFR) only within the scope of Union law (Article 51 CFR). Nevertheless, the essence of this freedom is also protected by the values of 'human

\footnotetext{
${ }^{5}$ In Bodnar's case, he probably acted in his official capacity as Ombudsman, thus raising issues of his powers rather than his fundamental rights.
} 
rights', 'rule of law' and 'democracy' enshrined in Article 2 TEU. ${ }^{6}$ As explained by the European Court of Human Rights ${ }^{7}$ and by the European Court of Justice in Tele2 Sverige, the freedom of expression is of 'particular importance ... in any democratic society'. It 'constitutes one of the essential foundations of a pluralist, democratic society, and is one of the values on which, under Article 2 TEU, the Union is founded'. ${ }^{8}$ This applies particularly to the essentials of this fundamental right - such as political speech. In this sense, the European Court of Human Rights constantly holds that 'there is little scope ... for restrictions on political speech or on debate on questions of public interest" including 'the functioning of the judiciary'. ${ }^{10}$ Thus, if a member state violates this 'essential foundation' of free political speech, it crosses a red line that delineates its very membership in the Union.

It should be noted that the limits of Article 51 CFR do not apply to Article 2 TEU and the values enshrined therein. As Advocate General Tanchev noted concisely:

The limits inherent in the Charter, to the effect that it only applies to Member States when they are implementing EU Law (Article 51(2) of the Charter) cannot be taken so far as to attenuate the duty ... to protect the fundamental values of the Union expressed in Article 2 TEU ... ${ }^{11}$

Therefore, relying on the 'essence' of a fundamental right under Article 2 TEU makes a great difference. To the extent that the freedom of expression falls under Article 2 TEU, political speech is protected under Union law against any measure of their home country that seriously infringes this value. ${ }^{12}$ This includes any judicial proceeding in Poland.

${ }^{6}$ On the relationship between Art. 2 TEU and Art. 51 CFR see L.S. Rossi, 'Il rapporto tra Trattato di Lisbona e Carta dei diritti fondamentali dell'UE', in G. Bronzini et al. (eds.), Le scommesse dell'Europa (Ediesse 2009) p. 73.

${ }^{7}$ See ECtHR [GC] 22 April 2013, Case No. 48876/08, Animal Defenders International v United Kingdom, paras. 102-103; ECtHR 26 November 1996, Case No. 17419/90, Wingrove v the United Kingdom, para. 58; ECtHR 8 July 1986, Case No. 9815/82, Lingens v Austria, para. 42.

${ }^{8}$ ECJ 21 December 2016, Cases C-203/15 and C-698/15, Tele2 Sverige, EU:C:2016:970, para. 93; ECJ 6 September 2011, Case C-163/10, Patriciello, EU:C:2011:543, para. 31.

${ }^{9}$ ECtHR [GC] 7 February 2012, Case No. 39954/08, Axel Springer AG v Germany, para. 90; ECtHR [GC] 22 October 2007, Case Nos. 21279/02 and 36448/02, Lindon, Otchakovsky-Laurens and July v France, para. 46; ECtHR [GC] 8 July 1999, Case Nos. 23927/94 and 24277/94, Sürek and Özdemir v Turkey, para. 46.

${ }^{10}$ ECtHR [GC] 23 June 2016, Case No. 20261/12, Baka v Hungary, para. 159; ECtHR [GC] 23 April 2015, Case No. 29369/10, Morice v France, para. 125; ECtHR 15 July 2010, Case No. 34875/07, Roland Dumas v France, para. 43.

${ }^{11}$ Opinion of Advocate General Tanchev, 20 June 2019, Case C-192/18, Commission v Poland, para. 72.

${ }^{12}$ For the full argument, see the second section. 


\section{The duty to interpret national law in conformity with Article 2 TEU values}

What does that mean for national officials involved in judicial proceedings against critics? Poland has not yet enacted specific laws targeting critical voices. Judicial proceedings are likely to rely on general laws, be it torts in private law (like slander), defamation in criminal law, or general clauses of disciplinary law. Given the openness of such general provisions, a judge can interpret and apply them in such a way as to sanction critical pronouncements.

Here, EU law steps in: its applicability and primacy in domestic proceedings bars such interpretation. This flows from the general EU principle that any domestic judge has to interpret and apply domestic law in conformity with EU law. ${ }^{13}$ Today, this includes the Union's common values enshrined in Article 2 TEU. Therefore, any member state judge has a duty to interpret any national law in conformity with Article 2 TEU values. ${ }^{14}$ Of course, the applicability of European values has been doubted. In two recent Grand Chamber decisions, however, the European Court of Justice determined that European values are to be applied by domestic courts, in particular when they protect the essence of a fundamental right (see in more detail infra under the heading 'The judicial applicability of Article 2 TEU values'). ${ }^{15}$ Hence, all national law, including domestic criminal, disciplinary, and private law, must be interpreted in light of European values, thereby protecting political free speech.

The same logic applies to a law explicitly permitting charges against a politically inconvenient person. An example can be found in the Hungarian laws directed against 'enemies' like the Open Society Foundation or the Central European University. ${ }^{16}$ If a domestic judge interprets and applies such laws, he or she

\footnotetext{
${ }^{13}$ See ECJ 6 November 2018, Case C-684/16, Max-Planck-Gesellschaft zur Förderung der Wissenschaften, EU:C:2018:874, para. 59; ECJ 6 November 2018, Case C-569/16, Bauer, EU: C:2018:871, para. 26; ECJ 13 July 2016, Case C-187/15, Pöpperl, EU:C:2016:550, para. 43; ECJ 24 May 2012, Case C-282/10, Dominguez, EU:C:2012:33, para. 27; ECJ 5 October 2004, Cases C-397/01 to C-403/01, Pfeiffer and Others, EU:C:2004:584, paras. 114, 115; S. Leible and R. Domröse, 'Interpretation in Conformity with Primary Law', in K. Riesenhuber (ed.), European Legal Methology (Intersentia, 2017) $\$ 8$, para. $38 \mathrm{ff}$.

${ }^{14} \mathrm{On}$ the interpretation of Union law in conformity with values, see M. Potacs, 'Wertkonforme Auslegung des Unionsrechts?', 51 EuR (2016) p. 164.

${ }^{15}$ ECJ 27 February 2018, Case C-64/16, Associação Sindical dos Juizes Portugueses, EU: C:2018:117; ECJ 25 July 2018, Case C-216/18 PPU, Minister for Justice and Equality, EU: C:2018:586.

${ }^{16}$ See European Parliament, Resolution of 17 May 2017 on the situation in Hungary, 2017/ 2656(RSP); see further P. Bárd, 'The rule of law and academic freedom or the lack of it in Hungary', European Political Science (2018); Z. Enyedi, 'Democratic Backsliding and Academic Freedom in Hungary', 16 Perspectives on Politics (2018) p. 1067.
} 
has to set it aside to the extent that it stands in conflict with a European value. This holds true for any official called upon to execute such a judicial decision or detention measure violating this freedom. ${ }^{17}$

\section{A duty of referral when Article 2 TEU is at stake?}

By giving such directions to national judges, Union law puts them in a difficult position, in particular in countries where the government's respect for judicial independence is low. Yet, a national judge does not stand alone but finds support in the European union of courts. Indeed, many Polish courts have turned to the European Court of Justice to support their independence. To further shield such judges, we hold that a national judge concerned with procedures brought against critics - or generally with cases in which Article 2 TEU values are at stake - is not only empowered but required under Union law to make a preliminary reference to the European Court of Justice. This duty rests on a seminal legal development: the protection of the Union's values has become as important as the uniform application of Union law.

Generally, only courts of last instance are under an obligation to make a reference when the application of EU law in the case at hand is surrounded by uncertainty (see Article 267(3) TFEU). According to the decision of the European Court of Justice in Foto-Frost, this obligation extends to lower courts where they doubt the validity of a provision of EU law. ${ }^{18}$ Before setting this provision aside, they have to refer the question of validity to the European Court of Justice. The underlying rationale is to preserve the effective and uniform application of EU law, which has been the Court's guiding star during the past six decades.

Now, with Opinion $2 / 13,{ }^{19}$ Associação Sindical dos Juizes Portugueses (ASJP), ${ }^{20}$ Achmea, ${ }^{21}$ L.M., ${ }^{22}$ and Wightman, ${ }^{23}$ the European Court of Justice has complemented this functional rationale with an axiological one. Today, 'values' figure as

\footnotetext{
${ }^{17}$ Generally, on the obligation of any public official to conform with EU law, see ECJ 4 December 2018, Case C-378/17, Garda Siochána, EU:C:2018:979, para. 38; ECJ 22 June 1989, Case C-103/ 88, Fratelli Costanzo, EU:C:1989:256, para. 32; ECJ 29 April 1999, Case C-224/97, Ciola, EU: C:1999:212, para. 30; see further M. Claes, The National Courts' Mandate in the European Constitution (Hart Publishing 2006) p. 266 ff.

${ }^{18}$ ECJ 22 October 1987, Case C-314/85, Foto-Frost, EU:C:1987:452; see further K. Lenaerts et al., EU Procedural Law (Oxford University Press 2014) para. $3.43 \mathrm{ff}$.

${ }^{19} \mathrm{ECJ} 18$ December 2014, Opinion 2/13, Accession of the EU to the ECHR, EU:C:2014:2454, para. 168.

${ }^{20}$ Associação Sindical dos Juizes Portugueses, supra n. 15, paras. 30-32.

${ }^{21}$ ECJ 6 March 2018, Case C-284/16, Achmea, EU:C:2018:158, para. 34.

${ }^{22}$ Minister for Justice and Equality, supra n. 15, paras. 35, 48, 50.

${ }^{23}$ ECJ 10 December 2018, Case C-621/18, Wightman, EU:C:2018:999, paras. 62-63.
} 
prominently as 'uniform application' and effet utile in the European Court of Justice's constitutional jurisprudence. Recognising the EU as a veritable 'Union of values', the Court forcefully protects its very foundations against the unprecedented challenges of the illiberal turn taken by some member states. In light of this new axiological rationale, the triad of Article 2 TEU, common values, and mutual trust stands on par with the triad justifying Foto-Frost - unity, coherence, and effet utile. We therefore suggest complementing the Foto-Frost logic: a national judge has not just the right but the outright duty to refer a case whenever the common value basis is in danger. Accordingly, a Polish judge, when faced with a case concerning the systematic silencing of critics, must refer the matter to the European Court of Justice and request an interpretation of Article 2 TEU in light of the rights at stake.

At first glance, such a duty seems to expand the European Court of Justice's reach immensely. However, a duty to refer cases to the European Court of Justice whenever the common value basis is in danger does not mean that a national judge has to refer every potential violation of an Article 2 TEU value to the Court. As we will explain later, Article 2 TEU is triggered only in exceptional situations and is subject to a rigid presumption of conformity (see infra under the heading 'Maintaining the federal balance'). Thus, the proposed duty to refer applies in very limited and extreme cases - it remains an exceptional obligation. Further, the proposed duty to refer not only entails a (limited) expansion of the European Court of Justice's reach; it should also support judges in difficult situations. Judges handling sensitive cases might be intimidated by political pressure or the threat of disciplinary measures (one need only remember the newly established disciplinary chamber at the Supreme Court). ${ }^{24}$ The European Court of Justice might shield those judges from governmental pressure, especially with the help of precautionary measures. As the interim measures in Commission v Poland have shown, the Polish government remains responsive to this basic layer of the European rule of law. ${ }^{25}$

But why does it have to be a duty? One could argue that leaving the decision to seek support from the European Court of Justice to the discretion of each judge is enough to protect them against external pressure. As courts in Łodz and Warsaw have proven, national judges deliberately seek the European Court of Justice's support. ${ }^{26}$ These judges are confronted with issues sensitive to the Polish

\footnotetext{
${ }^{24}$ Act on the (Polish) Supreme Court of 8 December 2017, Journal of Laws (2018), 5.

${ }^{25}$ See the Order of 19 October 2018 in Case C-619/18 R, Commission v Poland, EU: C:2018:852; for a more detailed reasoning, see Order of 17 December 2018 (EU:C:2018: 1021).

${ }^{26}$ See the pending preliminary references Miasto Łowicz v Skarb Państwa - Wojewoda Łódzki (C-558/18) and Prokuratura Okregowa w Ptocku v VX, WW, XV (C-563/18); see the similar reference in Prokuratura Rejonowa w Stubicach (C-623/18).
} 
government. They fear being subjected to disciplinary measures should they decide against the government and see their judicial independence at stake. ${ }^{27}$ Therefore, they have asked the European Court of Justice, based on its findings in ASJP, whether the newly introduced disciplinary measures for ordinary courts are in conformity with Article 19(1)(2) TEU, Article 47(1) CFR, and Article 2 TEU. As such, the mere possibility of being able to grasp the ECJ's helping hand appears to be enough.

Yet, two reasons seem to make a duty of referral necessary: first, cases in which Article $2 \mathrm{TEU}$ is at stake affect the Union's foundations and the basis for mutual trust between the member states. It cannot be left to a national court to unilaterally shape these foundations. This task can only be exercised coherently and uniformly by the highest court of the Union. Further, a duty protects national judges much better than discretion. The Polish government has already challenged the constitutionality of Article 267 TFEU as far as it regards the internal organisation of the judiciary ${ }^{28}$ and initiated disciplinary measures against judges referring to the European Court of Justice. ${ }^{29}$ Establishing a duty to refer would be a powerful response to any attempts to prohibit such references.

\footnotetext{
${ }^{27}$ On the disciplinary measures against Polish judges, see e.g. the open letter from Krystian Markiewicz, President of the Polish Judges Association Iustitia, to Frans Timmermans on 13 February 2019, available at 〈www.aeaj.org/blog/Situation-in-Poland_23_01_2019), visited 21 August 2019. For an account of already launched disciplinary measures, see Justice Defence Committee (KOS), 'A Country That Punishes. Pressure and Repression of Polish Judges and Prosecutors' (February 2019); Amnesty International, 'Poland: Free courts, free people, judges standing for their independence' (4 July 2019) p. 11 ff., p. 22 ff.; Helsinki Foundation, 'Disciplinary Proceedings against Judges and Prosecutors' (February 2019) p 6 ff.; D. Mazur, 'Judges under special supervision', Themis Association of Judges, Report, 5 April 2019, p. 38 ff.; European Stability Initiative, 'The disciplinary system for judges in Poland - The case for infringement proceedings', ESI-Batory Legal Opinion, 22 March 2019.

${ }^{28}$ The Prosecutor General and Minister of Justice have submitted a request to the Constitutional Tribunal asking it to assess whether Art. 267 TFEU, as far as it permits referring issues related to the system, form, and organisation of the judiciary, is in line with the Polish constitution (pending as Case K 7/18), see S. Biernat and M. Kawczyńska, 'Though this be madness, yet there's method in't: Pitting the Polish Constitutional Tribunal against the Luxembourg Court', Verfassungsblog, 26 October 2018.

${ }^{29}$ Polish authorities (the Deputy Disciplinary Prosecutor for Common Courts) have already summoned several judges to submit written statements after they requested preliminary rulings on the conformity of the new disciplinary measures with EU law (supra n. 26), implying that they had committed a 'juridical excess'; see Themis, 'Position of The Association Of Judges, "Themis", In Connection With The Disciplinary Actions Against The Authors Of The Questions Referred for Preliminary Rulings', 15 December 2018, at /themis-sedziowie.eu/materials-in-english/positionof-the-association-of-judges-themis-in-connection-with-the-disciplinary-actions-against-the-authorsof-the-questions-referred-for-preliminary-rulings/ $\rangle$, visited 21 August 2019.
} 


\section{The last resort: criminal liability for disrespecting union values}

But what happens if a judge does not respect the values enshrined in Article 2 TEU and silences critics with his or her decisions? Indeed, quite a few judges owe their position to the recent overhaul of the Polish judiciary and are considered to be sympathetic to the government's agenda. We argue that if they severely and knowingly disrespect the primacy of Union law, they could face criminal liability. Why?

Let's take a step back: severely and knowingly exceeding public powers, especially as a judge, is sanctioned in most legal orders. ${ }^{30}$ The relevant provisions of the Polish Criminal Code provide a good description of the various forms this may take. For example, Article 231(1) punishes the general excess of authority: 'A public official who, by exceeding his or her authority, or not performing his or her duty, acts to the detriment of a public or individual interest, is liable to imprisonment for up to three years'. This includes - under strict conditions - also the activity of judges. ${ }^{31}$

Without a doubt, judges can err. As such, not just any judicial decision violating the law is per se a perversion of justice. Indeed, non-accountability is a core element of judicial independence. According to Advocate General Ruiz-Jarabo Colomer, 'impartiality and independence are fragile virtues which must be very rigorously protected' ${ }^{32}$ An independent judiciary is not only a manifestation of the separation of powers but also an inherent component of effective judicial protection. ${ }^{33}$ At the same time, this independence is in continuous

\footnotetext{
${ }^{30}$ See e.g. the seminal contribution of M. Cappelletti, “Who Watches the Watchmen?" A Comparative Study on Judicial Responsibility', 31 American Journal of Comparative Law (1983) p. 1; for Germany, see M. Uebele, ' $\$ 339$ StGB', in W. Joecks and Miebach (eds.), Münchener Kommentar zum StGB, $3^{\text {rd }}$ edn. (C.H. Beck 2019); T. Singelnstein, Strafbare Strafverfolgung (Nomos 2019) p. 157 ff.; for France, see G. Canivet and J. Joly-Hurard, 'La Responsabilité des Juges, Ici et Ailleurs', 58 Revue International de Droit Comparé (2006) p. 1049; G. Bolard, 'De la responsabilité pénale du juge', 49 La Semaine Juridique (2005) p. 2247; for Spain, see L.M. Díez-Picazo, 'Judicial Accountability in Spain: An Outline', in G. Canivet et al. (eds.), Independence, Accountability and the Judiciary (BIICL 2006) p. 211; for Italy, see G. Fiandaca, 'Sulla Responsabilità Penale del Giudice', 132 Il Foro Italiano (2009) p. 409; A. Giuliani and N. Picardi, La Responsabilità Del Giudice (Giuffrè 1995); for Romania, see R. Coman and C. Dallara, 'Judicial Independence in Romania', in A. Seibert-Fohr (ed.), Judicial Independence in Transition (Springer 2012) p. 835, $863 \mathrm{ff}$.

${ }^{31}$ For an application of that provision to judges (yet not a conviction) see e.g. Polish Supreme Court, 30 August 2013, SNO 19/13. On the questionable current use of Art. 231 with regard to judges, see the critical report of Mazur, supra n. 27, p. $26 \mathrm{ff}$.

${ }^{32}$ See Opinion of Advocate General Colomer, 28 June 2001, Case C-17/00, De Coster, para. 93.

${ }^{33}$ With regard to Art. 47 CFR, see recently Minister for Justice and Equality, supra n. 15, paras. 48, 54, 63-67; Associação Sindical dos Juizes Portugueses, supra n. 15, paras. 42, 44; ECJ 14 June 2017,
} 
conflict with a judge's obligation to observe the law. A careful balance has to be struck between these competing elements. ${ }^{34}$ Even if different standards apply in each member state, it is obvious that the criminal liability of judges can apply only ultima ratio - it is confined to very exceptional cases. Further, special procedural safeguards must be in place. This is particularly true in Poland, where judicial immunity is explicitly enshrined in the Constitution (see Articles 173, 180(1) and (2) and 181 of the Polish Constitution). ${ }^{35}$

How does this relate to Union law? At first sight there are two ways to construe this argument: first, EU law is an independent source of law in national procedures. The principles of primacy and direct effect require a domestic judge to directly apply EU law and eventually to disapply or re-interpret conflicting national laws. Thus, it makes no difference whether a national judge disregards national or Union law - both are equally capable of triggering the criminal liability of a judge. Second, according to an established line of jurisprudence, 'infringements of EU law must also - at the very least — be punishable under conditions, both procedural and substantive, which are analogous to those applicable to infringements of national law of a similar nature and importance $e^{36}$

Case C-685/15, Online Games e. a., EU:C:2017:452, para. 60 ff.; ECJ 19 September 2006, Case C-506/04, Wilson, EU:C:2006:587, para. $49 \mathrm{ff}$.; on the importance of judicial independence under Art. 6 ECHR, see ECtHR [GC] 6 November 2018, Case No. 55391/13, Ramos Nunes De Carvalho v Portugal, para. 144 ff.; ECtHR [GC] 18 July 2013, Case No. 2312/08 and 34179 v 08, Maktouf and Damjanovic v Bosnia and Herzegovina, para. 49; ECtHR 21 July 2009, Case No. 34197/02, Luka v Romania, para. 37; ECtHR 3 March 2005, Case No. 54723/00, Brudnicka and Others v Poland, para. 41; ECtHR [GC] 6 June 2003, Case No. 39343/98, Kleyn and Others $\mathrm{v}$ the Netherlands, para. 190 ff.; ECtHR 24 November 1994, Case No. 15287/89, Beaumartin v France, para. 38; ECtHR 22 October 1984, Case No. 8790/79, Sramek v Austria, para. 38; ECtHR 28 June 1984, Case No. 7819/77, Campbell and Fell v the United Kingdom, para. 78; see further L.F. Müller, Richterliche Unabhängigkeit und Unparteilichkeit nach Art. 6 EMRK (Duncker \& Humblot 2015).

${ }^{34}$ On this general tension, see M. Rheinstein, 'Who Watches the Watchmen?', in P. Sayre (ed.), Interpretations of Modern Legal Philosophy (Oxford University Press 1981) p. 589; D. Brüggemann, 'Qui custodit custodem?', in D. Brüggemann, Die Rechtsprechende Gewalt (De Gruyter 1961) p. 179; specifically on the criminal liability of judges, see M. Hoenigs, 'Der Straftatbestand der Rechtsbeugung: Ein Normativer Antagonismus zum Verfassungsprinzip der richterlichen Unabhängigkeit', 92 Kritische Vierteljahresschrift 92 (2009) p. 303; P.-A. Albrecht, 'Die Kriminalisierung der Dritten Gewalt', 37 Zeitschrift für Rechtspolitik (2004) p. 259.

${ }^{35}$ On the importance of judicial immunity in Poland, see Polish Constitutional Tribunal, 28 November 2007, K 39/07; 2 May 2015, P 31/12; on the special procedure for lifting the judicial immunity, see A. Bodnar and L. Bojarski, 'Judicial Independence in Poland', in Seibert-Fohr, supra n. 30 , p. 667,716 .

${ }^{36}$ See Opinion of Advocate General Kokott, 30 April 2015, Case C-105/14, Taricco, EU: C:2015:293, para. 80 (emphasis added); see further ECJ 2 May 2018, Case C-574/15, Scialdone, EU:C:2018:295, para. 28; ECJ 19 July 2012, Case C-263/11, Rèdlihs, EU: C:2012:497, para. 44; ECJ 28 October 2010, Case C-367/09, SGS Belgium, EU:C:2010:648, para. 
This member state obligation is ultimately a specific expression of the principles of effectiveness and equivalence. In short, this means: 'Member States are required ... to penalise any persons who infringe [Union] law in the same way as they penalise those who infringe national law'. ${ }^{37}$ If - under national criminal law - the deliberate disregard of constitutional law or a verdict of the constitutional court is a criminal offence, then the same must apply in cases where a national judge knowingly disregards EU law or, specifically, a judgment of the European Court of Justice delivered in the case at hand.

What are the applicable standards? Determining the thresholds for the criminal liability of judges - even if they disregard Union law - is a matter of national criminal law. Yet, EU law can provide some inspiration for the applicable standards: one need only recall the European Court of Justice's Köbler jurisprudence, which limits the action for damages for the disrespect of Union law to a 'manifest breach of the case-law of the Court in the matter'. ${ }^{38}$ If this standard already applies to state liability, then the personal criminal liability of judges must be subject to even higher thresholds. A limit will be probably reached where a judge severely and knowingly violates the applicable law to the detriment of a party in the proceedings. To clarify this with an example: Let's assume a Constitutional Court decides to strike down a specific law or to declare a certain interpretation of that law as unconstitutional. If judges knowingly disregard these dicta and continue to apply said law (or the unconstitutional interpretation thereof) to silence government critics, they exceed their powers and trigger their criminal responsibility.

41; ECJ 3 May 2005, Cases C-387/02, C-391/02 and C-403/02, Berlusconi and Others, EU: C:2005:270, para. 65; ECJ 30 September 2003, Case C-167/01, Inspire Art, EU:C:2003:512, para. 62; ECJ 8 July 1999, Case C-186/98, Nunes and de Matos, EU:C:1999:376, para. 10; ECJ 27 February 1997, Case C-177/95, Ebony Maritime and Loten Navigation, EU:C:1997:89, para. 35; ECJ 26 October 1995, Case C-36/94, Siesse, EU:C:1995:351, para. 20; ECJ 10 July 1990, Case C 326/88, Hansen, EU:C:1990:291, para. 17; see further K. Lenaerts and J.A. GutiérrezFons, 'The European Court of Justice and fundamental rights in the field of criminal law', in V. Mitsilegas et al. (eds.), Research Handbook on EU Criminal Law (Edward Elgar 2016) p. 7 ff.; M. Dougan, 'From the Velvet Glove to the Iron Fist: Criminal Sanctions for the Enforcement of Union Law', in M. Cremona (ed.), Compliance and the Enforcement of EU Law (Oxford University Press 2012) p. 74; H. Satzger, Internationales und Europäisches Strafrecht, $8^{\text {th }}$ edn. (Nomos 2018) p. 133-144; M. Heger, 'Einwirkungen des Europarechts auf das nationale Strafrecht', in M. Böse (ed.), Europäisches Strafrecht, Enzyklopädie Europarecht, Vol 9 (Nomos 2013) $\$ 5$, para. $8 \mathrm{ff}$.

${ }^{37}$ ECJ 21 September 1989, Case C-68/88, Commission v Greece, para. 22.

${ }^{38}$ ECJ 30 September 2003, Case C-224/01, Köbler, EU:C:2003:513, para. 56; on this, see Z. Varga, 'In Search of a "Manifest Infringement of the Applicable Law" in the Terms set out in Köbler', 9 Review of European Administrative Law (2016) p. 5; J.-P. Terhechte, 'Judicial Accountability and Public Liability - The German "Judges Privilege" Under the Influence of European and International Law', 13 German Law Journal (2012) p. 313. 
When is this threshold reached with regard to EU law? A 'severe' infringement will be unlikely to occur in the day-to-day application of EU law. The threshold could be reached when Article 2 TEU values are violated. ${ }^{39}$ Admittedly, these values are vague and open and thus difficult to apply. However, this neither excludes their legal nature nor their judicial applicability. ${ }^{40}$ Accordingly, national law must be applied and interpreted in a way that complies with Article 2 TEU. ${ }^{41}$ This includes the shape and form that these values have acquired through the European Court of Justice's interpretation. The Court's interpretation of EU law - articulated in preliminary rulings - has legally binding force. ${ }^{42}$ Therefore, the disregard of a consolidated European Court of Justice jurisprudence is unlawful unless it is referred to the Court again. ${ }^{43}$ As such, the values of Article 2 TEU in their interpretation by the European Court of Justice represent a suitable starting point for national provisions establishing the criminal liability of judges. In addition to these high substantive requirements, there will be considerable difficulties in proving the intention of the judge concerned, i.e. to substantiate that he or she knew the relevant law and deliberately disregarded its effects. Due to the uncertainties surrounding the complex interplay of Union and national law, a simple error of law will be difficult to exclude in most cases. Determining this intention falls to the trial judge. But here again, actions by European institutions will be important: if a Polish judge knowingly disrespects a European Court of Justice decision that protects free speech in the case at hand, a red line and, in all likelihood, the threshold of criminal liability are crossed. Hence, pronouncements of the European Court of Justice are key. For that

${ }^{39}$ On the exceptional nature of these violations, see text to $\mathrm{n}$. $122 \mathrm{ff}$ infra.

${ }^{40} \mathrm{On}$ the construction of this applicability, see text to $\mathrm{n}$. $64 \mathrm{ff}$ infra.

${ }^{41}$ On the duty to interpret in conformity with values, see text to n. 13 supra.

${ }^{42}$ See on this Lenaerts et al., supra n. 18, paras. 5.70, 6.30 ff. (p. 244-246); M. Broberg and N. Fenger, Preliminary References to the European Court of Justice, $2^{\text {nd }}$ edn. (Oxford University Press 2014) p. 450 ff.; U. Karpenstein, 'Art. 267 AEUV', in E. Grabitz et al. (eds.), Das Recht der Europäischen Union, 65 ${ }^{\text {th }}$ edn. (C.H. Beck 2018) para. 104 ff; C.F. Germelmann, Die Rechtskraft von Gerichtsentscheidungen in der Europäischen Union (Mohr Siebeck 2009) p. 410 ff.; A. Trabucchi, 'L'Effet "erga omnes" des décisions préjudicielles rendues par la Cour de justice des Communautés européennes', 10 Revue trimestrielle de droit européen (1976) p. 56; against a legally binding force, see R. Schütze, European Union Law (Cambridge University Press 2018) p. 399 ff.

${ }^{43}$ This is undoubtedly the case for courts of last instance, while a similar binding force (together with an obligation to refer) is discussed for lower courts, see Lenaerts et al., supra n. 18, para. 3.61; in favour, see Broberg and Fenger, supra n. 42, p. 265 ff.; H. Kanninen, 'La marge de manoeuvre de la juridiction suprème nationale pour procéder à un renvoi préjudiciel à la Cour de justice des Communautés européennes', in N. Colneric et al. (eds.), Une Communauté de droit (BWV 2003) p. 611, 613 ff.; against, see B. Wegener, 'Art. 267 AEUV', in C. Calliess and M. Ruffert (eds.), EUVIAEUV, $5^{\text {th }}$ edn. (C.H. Beck 2016) para. 49. 
reason, the European Commission should follow the situation closely and initiate infringement proceedings in a timely manner, in a way that a decision of the European Court of Justice can trigger the effects sketched above. ${ }^{44}$

What does that mean for cases like Bodnar and Sadurski? By interpreting the respective legal basis for slander or defamation in a way that bluntly violates the freedom of speech as enshrined in Article 2 TEU, a judge disregards these values. In our view, such a decision would not only violate Article 2 TEU but might also infringe the principle of nulla poena sine lege. This principle is enshrined in the Universal Declaration, Article 15 ICCPR, Article 7 ECHR, Article 49(1) CFR, and, not least, Article 42(1) Polish Constitution. Its importance to the European legal order has recently been stressed by the Taricco saga. ${ }^{45}$ It is not only infringed when a legal basis is missing (meaning: non-existent ${ }^{46}$ ) but also in cases of arbitrary judicial interpretation of said basis. According to the European Court of Human Rights, 'Article 7 of the Convention cannot be read as outlawing the gradual clarification of the rules of criminal liability through judicial interpretation from case to case, provided that the resultant development is consistent with the essence of the offence and could reasonably be foreseen ${ }^{.7}{ }^{4}$ An interpretation of a provision as criminalising political speech protected under Article 2 TEU would be neither consistent with the essence of the offence nor foreseeable. If there is, on top of this, a decision of the European Court of Justice

\footnotetext{
${ }^{44}$ Recent infringement proceedings by the Commission demonstrate that the conduct of courts (and even the disregard of the duty to refer under Art. 267(3) TFEU) is also subject to Art. 258 TFEU, see ECJ 4 October 2018, Case C-416/17, Commission v France, EU:C:2018:811, para. 100 ff.; see further ECJ 12 November 2009, Case C-154/08, Commission v Spain, EU:C:2009:695, para. 125; ECJ 9 December 2003, Case C-129/00, Commission v Italy, EU:C:2003:656, para. 29.

${ }^{45}$ ECJ 5 December 2017, Case C-42/17, M.A.S. and M.B., EU:C:2017:936, para. 51 ff.; see further ECJ 3 May 2007, Case C-303/05, Advocaten voor de Wereld, EU:C:2007:261, para. 46; M. Timmerman, Legality in Europe: On the Principle Nullum Crimen, Nulla Poena Sine Lege in EU Law and Under the ECHR (Intersentia 2018) p. $147 \mathrm{ff}$.

${ }^{46} \mathrm{In}$ cases based on the general provisions of slander or defamation, a legal basis would still exist.

${ }^{47}$ See recently ECtHR, 17 October 2017, Case No. 101/15, Navalnyye v Russia, para. 55 (emphasis added); see further ECtHR [GC] 27 January 2015, Case No. 59552/08, Roblena v the Czech Republic, para. 51; ECtHR [GC] 22 March 2001, Case No. 37201/97, K.-H. W. v Germany, para. 45; ECtHR [GC] 22 March 2001, Case Nos. 34044/96, 35532/97 and 44801/ 98, Streletz, Kessler and Krenz v Germany, para. 50; ECtHR 22 November 1995, Case No. 20166/92, S.W. v the United Kingdom, para. 36; see also C. Grabenwarter and K. Pabel, Europäische Menschenrechtskonvention, $6^{\text {th }}$ edn. (C.H. Beck 2016) $\$ 24$, para. 156; the ECJ employs a similar conception ('reasonably foreseeable'), see ECJ 20 December 2017, Case C-102/16, Vaditrans, EU:C:2017:1012, para. 52; ECJ 22 October 2015, Case C-194/14 P, AC-Treuhand, EU: C:2015:717, para. 41; ECJ 28 June 2005, Cases C-189/02 P e.a., Dansk Rørindustri and Others v Commission, EU:C:2005:408, para. 217 ff; A. Eser, 'Art. 49 GRC', in J. Meyer (ed.), Charta der Grundrechte der Europäischen Union, $4^{\text {th }}$ edn. (Nomos 2014), para. 25.
} 
protecting the freedom of expression in the specific case, the respective judge's criminal liability could not be ruled out.

Two fundamental objections to these conclusions could be raised: first, the criminal liability of judges for infringements of Union law could be understood as an inadmissible harmonisation of the substantive criminal law of the member states. The exercise of criminal justice is a competence firmly in the hands of the member states, and so it remains in our proposal. Violating EU law severely and knowingly is only a point of reference for national offences stipulating the criminal liability of judges. It neither extends the competences of the Union institutions nor influences the substantive criminal law of the member states.

Second, our proposal could have unforeseeable implications for the relationship of national judges and the Union legal order. The trust of national courts in EU law and their essential cooperation with the Court of Justice could be severely damaged ${ }^{48}$ and its authority dangerously undermined. ${ }^{49}$ However, there are two rejoinders to such a threat. On one hand, the criminal liability of judges, as shown above, is limited to extreme cases and only applies under very narrow conditions. On the other hand, criminal proceedings against judges deliberately violating Union values are part of a national process to restore the rule of law. These trials are conducted before national courts in accordance with national criminal law. After all, such proceedings could be used to counter a frequently voiced criticism: some have identified the one-sided 'judicialisation' of politics in the context of the EU's eastward enlargement as a central cause for the emergence of populism and its thrust against a 'pathologically' strong judiciary. ${ }^{50}$ The critical reforms are seen as reactions to the 'rise of the unelected' favoured by the EU: an all too strong judiciary that has lost its feedback to the democratic process and is not accountable to anyone. The criminal liability of judges violating the Union's common values would send a clear signal that there are also red lines for the judiciary: the values enshrined in Article 2 TEU.

\footnotetext{
${ }^{48} \mathrm{On}$ the trust of national judges in the ECJ, see J. Mayoral, 'In the CJEU Judges Trust: A New Approach in the Judicial Construction of Europe', 55 JCMS (2016) p. 551.

${ }^{49} \mathrm{So}$ far, the authority of the ECJ has been spared (with a few exceptions) from the increasing backlash against international courts, see A. Hofmann, 'Resistance against the Court of Justice of the European Union', 14 International Journal of Law in Context (2018) p. 258.

${ }^{50} \mathrm{M}$. Mendelski, 'Das europäische Evaluierungsdezifit der Rechtsstaatlichkeit', 44 Leviathan (2016) p. 366 at p. 391; J.E. Moliterno et al., Independence without Accountability: The Harmful Consequences of EU Policy Toward Central and Eastern European Entrants', 42 Fordham International Law Journal (2018) p. 481; C. Parau, 'The dormancy of parliaments: The invisible cause of judiciary empowerment in Central and Eastern Europe', 49 Representation (2013) p. 267. Taking it to the extreme, see K.L. Scheppele, 'Democracy by Judiciary (Or Why Courts Can Sometimes Be More Democratic Than Parliaments)', in A. Czarnota et al. (eds.), Rethinking the Rule of Law in Post-Communist Europe (CEU Press 2005) p. 25.
} 
Admittedly, it seems rather unlikely that judges or politicians who severely and knowingly violated Union values will face prosecution anytime soon. But no government lasts forever. Biased public officials can be held accountable once the political landscape has changed. Such criminal proceedings do not constitute an unacceptable 'victor's justice' if they are pursued in a manner that is itself respectful of the Union's common values. ${ }^{51}$ As such, they might be an important tool to re-establish a judicial system in line with the rule of law. ${ }^{52}$ Certainly, the illiberal tendencies in Poland or Hungary are not close to reaching the level of injustice of totalitarian regimes yet. In this respect, we can only hope that our final conclusion will remain a hypothetical thought experiment and that the persecution of government critics will not develop any systematic traits. If this should happen, however, Union law and (in the long run) national criminal law will provide the starting points for a powerful response.

\section{Legal FRAming VIA the Solange Doctrine}

These proposed ways have one thing in common: they are aimed at putting Article 2 TEU values into judicial practice. Nevertheless, it is evident that such proposals could potentially uproot the federal balance established by the Treaties to the detriment of national autonomy, identity and diversity. A massive power shift to the Union should be avoided, not least because it would threaten the Union itself as vigorous national countermeasures would be likely.

We think that the Reverse Solange doctrine provides a fitting legal justification and reconstruction of our proposals, as it succeeds in judicially applying Article 2 TEU against the unexpected challenges by authoritarian tendencies while maintaining the European federal balance, i.e. the order of tasks and competences between the EU and its member states epitomised by Article 51(1) CFR. In the following, we will first present the Reverse Solange doctrine (see infra under the heading 'The doctrine's basic logic and elements') and concentrate on one of its central premises: the judicial applicability of Article 2 TEU. Taking into account recent case law of the European Court of Justice, we will demonstrate how a judicial application of Article 2 TEU can be construed (see infra under the heading 'The judicial applicability of Article 2 TEU values'). So as not to compromise the federal balance, Article $2 \mathrm{TEU}$ is subject to very high substantive standards. Furthermore, a Solange presumption in favour of member state

\footnotetext{
${ }^{51} \mathrm{On}$ the risks of instrumentalising such procedures, see I. Müller, 'Die Verwendung des Rechtsbeugungstatbestands zu politischen Zwecken', 17 Kritische Justiz (1984) p. 119.

${ }^{52} \mathrm{On}$ such processes, see A. Eser et al. (eds.), Strafrecht in Reaktion auf Systemunrecht: Vergleichende Einblicke in Transitionsprozesse. Teilband 14: Transitionsstrafrecht und Vergangenheitspolitik (Duncker \& Humblot 2012).
} 
compliance applies, which is only rebutted if a high threshold has been transgressed (see infra under the heading 'Maintaining the federal balance').

\section{The doctrine's basic logic and elements}

The Reverse Solange doctrine ${ }^{53}$ emerged in 2012 to confront severe restrictions on media freedom in Hungary under Union law - restrictions which, although beyond the scope of the CFR, put the very terms of membership (Article 49(1) TEU) into question. The doctrine was conceived because responses by the Council of Europe appeared too weak and an Article 7 TEU response too remote.

Much has happened since 2012. On the one hand, national measures of the Hungarian type have become ever more frequent, amounting to a larger illiberal turn. The aforementioned proceedings against Bodnar and Sadurski are just the tip of the iceberg. Today, such measures are threatening the Union's values on a systemic scale: if not confronted, they might even start informing the values of Article 2 TEU, thus affecting the Union's very nature. ${ }^{54}$ On the other hand, there are the European Court of Justice's path-breaking pronouncements

${ }^{53}$ A. von Bogdandy et al., 'Reverse Solange - Protecting the Essence of Fundamental Rights Against EU member states', 49 CML Rev (2012) p. 489; A. von Bogdandy et al., 'A European Response to Domestic Constitutional Crisis: Advancing the Reverse Solange Doctrine', in A. von Bogdandy and P. Sonnevend (eds.), Constitutional Crisis in the European Constitutional Area. Theory, Law and Politics in Hungary and Romania (Hart Publishing 2015) p. 235; A. von Bogdandy et al., 'Protecting EU Values: Reverse Solange and the Rule of Law Framework', in A. Jakab and D. Kochenov (eds.), The Enforcement of EU Law and Values (Oxford University Press 2017) p. 218. For an evaluation, see the discussion of D. Halberstam et al. in M. Steinbeis et al. (eds.), Gebändigte Macht: Verfassung im Europäischen Nationalstaat (Nomos 2015); for further discussions, see e.g. D. Sarmiento and E. Sharpston, 'European Citizenship and Its New Union: Time to Move On?', in D. Kochenov (ed.), EU Citizenship and Federalism: The Role of Rights (Cambridge University Press 2017) p. 226, 240; M. van den Brink, 'The Origins and the Potential Federalising Effects of the Substance of Rights Test', in Kochenov (ed.) supra, p. 85; J. Croon-Gestefeld, 'Reverse Solange - Union Citizenship as a Detour on the Route to European Rights Protection Against National Infringements', in Kochenov (ed.) supra, p. 371; M. Blauberger, 'Europäischer Schutz gegen nationale Demokratiedefizite?' 44 Leviathan (2016) p. 280, 289 ff.; C. Franzius, 'Grundrechtsschutz in Europa - Zwischen Selbstbehauptungen und Selbstbeschränkungen der Rechtsordnungen und ihrer Gerichte', 75 Zeitschrift für ausländisches Öffentliches Recht und Völkerrecht (2015) p. 405; S. Iglesias Sánchez, 'Fundamental Rights and Citizenship of the Union at Crossroads: A Promising Alliance or a Dangerous Liaison?', 20 ELJ (2014) p. 477; M. Klatt, Die Praktische Konkordanz von Kompetenzen. Entwickelt anhand der Jurisdiktionskonflikte im europäischen Grundrechtsschutz (Mohr Siebeck 2014) p. 395-406; A.M. Russo, 'La cittadinanza "sostanziale" dell'UE alla luce della proposta del gruppo di Heidelberg: verso una "reverse Solange"?' 1 Federalismi (2014) p. 1; D. Kochenov, 'On Policing Article 2 TEU Compliance - Reverse Solange and Systemic Infringements Analyzed', 33 Polish Yearbook of International Law (2013) p. 145.

${ }^{54} \mathrm{~A}$. von Bogdandy et al., 'Guest Editorial: A potential constitutional moment for the European rule of law - The importance of red lines', 55 CML Rev (2018) p. 983. 
confronting such developments, a general deepening of the constitutional character of Union law as well as a blossoming of judicial cooperation in the European legal space. Against this backdrop, the Reverse Solange doctrine will justify our proposals as well as the Court's pertinent case law and counter fears of an illegal or illegitimate competence creep.

At its heart, the doctrine shows how any court in the European legal space, including the Court of Justice, can scrutinise any national measure by relying on the standards of Article 2 TEU. The basic idea is to put the Union's weight behind national institutions and citizens resisting such restrictions. So as not to upset the federal balance epitomised by Article 51 CFR, the doctrine categorically limits such scrutiny to situations which threaten essential norms, i.e. the values of the EU. Nevertheless, the doctrine provides for some level of general applicability for the Charter of Fundamental Rights, namely to the extent that the essence of a Charter right substantiates an Article 2 TEU value.

Like the Italian controlimiti doctrine, ${ }^{55}$ any Solange doctrine is about articulating and protecting essential conditions for cooperation between distinct legal orders. This doctrine was originally formulated by a national institution (the German Constitutional Court) operating under a national constitution against acts of a supranational institution (the European Community). ${ }^{56}$ Yet, the concept is not limited to that vertical relationship but allows to be applied to practically any context involving cooperation between legal orders. ${ }^{57}$ In this sense, the logic can be applied in the form of a horizontal Solange doctrine to the cooperation between member states. ${ }^{58}$ As the judgments in Kadi ${ }^{59}$ (EU-UN Security Council) or Bosphorus ${ }^{60}$ and Avotins $^{61}$ (ECHR-EU) demonstrate, the doctrine also extends to the diagonal relationship between supranational and international organisations.

${ }^{55}$ See e.g. Corte Costituzionale, 18 December 1973, 183/1973, Frontini, para. 9; 5 June 1984, 170/1984, Granital, para. 7; 15 December 1988, 1146/1988, para. 2.1; 13 April 1989, 232/1989, Fragd, para. 3.1; more recently, see 19 March 2001, 73/2001, para. 3.1; 4 July 2007, 284/2007, para. 3; 13 February 2008, 102/2008, para. 8.2.8.1 and the Order of 23 November 2016, 24/2017, para. 7 referring the Taricco case to the ECJ.

${ }^{56}$ Bundesverfassungsgericht [BVerfG], 29 May 1974, 2 BvL 52/71, Solange I, para. 62; 22 October 1986, 2 BvR 197/83, Solange II, para. 132; 7 June 2000, 2 BvL 1/97, Bananenmarkt, para. 57.

${ }^{57}$ On the different settings, see A. Tzanakopoulos, 'Judicial dialogue in multilevel governance: the impact of the Solange Argument', in O.K. Fauchald and A. Nollkaemper (eds.), The Practice of International and National Courts and the (De-)Fragmentation of International Law (Hart Publishing 2012) p. 185.

${ }^{58}$ I. Canor, 'My brother's keeper? Horizontal Solange: "An ever closer distrust among the peoples of Europe"', 50 CML Rev (2013) p. 383.

${ }^{59}$ ECJ 3 September 2008, Cases C-402/05 P and C-415/05 P, Kadi, EU:C:2008:461, para. 256.

${ }^{60} \mathrm{ECtHR}$ [GC] 30 June 2005, Case No. 45036/98, Bosphorus v Ireland.

${ }^{61}$ ECtHR [GC] 23 May 2016, Case No. 17502/07, Avotinš̌ v Latvia. 
A Solange doctrine, which is based on Article 2 TEU, concerns the relationship between the EU and its member states. It functions in exactly the opposite way as the original model and can, therefore, be referred to as the Reverse Solange doctrine'.

As with all Solange doctrines, Reverse Solange's very function is to frame the basic relationship between interconnected but autonomous legal orders by articulating and protecting essential conditions for cooperation. Cooperation can go ahead 'as long as' (i.e. solange) these essentials are met. The inner structure of most Solange doctrines, including Reverse Solange, consists of three elements. First, essential standards defined by one legal order (A) are applied to acts of another legal order (B) as a prerequisite for cooperation. Second, the doctrine presupposes that the courts of legal order A are empowered to review acts of legal order B with regard to whether they meet those standards. Third, building on the seminal Solange II decision of the German Federal Constitutional Court, most doctrines, including Reverse Solange, establish the presumption - in legal order A - that acts emanating from legal order $\mathrm{B}$ comply with those standards. This presumption facilitates cooperation, not least by setting a high threshold for its rebuttal. Its very creator, the German Federal Constitutional Court, has thus far never interrupted cooperation.

The doctrine's genius results from combining two seemingly opposite logics: on the one hand the pluralist premise that the cooperating legal orders remain diverse; on the other, the constitutionalist and even axiological premise that some standards cannot be forgone. How does the doctrine achieve this balance? First, by setting a high threshold to rebut the presumption of conformity, and second, by concentrating only on the essential preconditions for cooperation, i.e. the 'Geschäftsgrundlage' underlying the actual cooperation. With regard to the EU and its member states, this includes the conditions of membership set out in Articles 2 and 49 TEU in particular. Accordingly, Reverse Solange looks at member states through the prism of a different rationale than the Charter of Fundamental Rights. The dominant logic of the latter's application to the member states is to safeguard the uniform application of Union law. ${ }^{62}$ In this sense, it has gained

\footnotetext{
${ }^{62}$ According to the Court, the Charter's aim is primarily 'to avoid a situation in which the level of protection of fundamental rights varies according to the national law involved in such a way as to undermine the unity, primacy and effectiveness of EU law', see ECJ 16 February 2013, Case C-399/11, Melloni, EU:C:2013:107, para. 60; ECJ 6 March 2014, Case C-206/13, Siragusa, EU: C:2014:126, para. 32; for the locus classicus of this critique, see J. Coppel and A. O'Neill, 'The European Court of Justice: Taking Rights Seriously?, 29 CML Rev (1992) p. 669, 670; see also E. Spaventa, The Interpretation of Article 51 of the EU Charter of Fundamental Rights (European Parliament, PETI-Committee, 2016) p. 21; M. Dougan, 'Judicial Review of Member State Action Under the General Principle and the Charter: Defining the "Scope of Union Law", 52 CML Rev (2015) p. 1201 at p. 1240 ff.; H.J. Cremer, 'Funktionen der Grundrechte', in C. Grabenwarter (ed.), Enzyklopädie Europarecht, Vol II: Europäischer Grundrechtsschutz (Nomos 2014) § 1 para. 127.
} 
currency in the day-to-day legal operations under Union law. By contrast, the Reverse Solange doctrine regards the essential values upon which those day-to-day operations are based (Articles 2 and 49 TEU). It only applies to exceptional circumstances.

With regard to EU fundamental rights, the Reverse Solange doctrine operates as follows: beyond the scope of Article 51(1) CFR, any member state remains autonomous in its fundamental rights protection as long as (Solange) the presumption holds that it respects the essence of fundamental rights enshrined in Article 2 TEU. All courts in the $\mathrm{EU}$ are competent to police this presumption. If the presumption is rebutted, the EU mechanisms for protecting the Union's common values apply.

Yet, the doctrine rests on one critical premise: it presupposes the judicial applicability of Article 2 TEU values. Such application is not a given and needs to be carefully construed. Although it seems uncontested that the values of Article 2 TEU apply to any act by any member state irrespective of any other link to EU law, ${ }^{63}$ it is much less clear if and how the values of Article 2 TEU have legal and justiciable effects. The following section will address these uncertainties and demonstrate how the judicial applicability of Union values can be construed.

\section{The judicial applicability of Article 2 TEU values}

\section{Questions of method}

It is not self-evident that Article 2 TEU values extend justiciable legal effects. Some even doubt their status as law. ${ }^{64}$ Such doubts are hardly convincing. The values of Article 2 TEU are laid down in the operative part of a legal text -

\footnotetext{
${ }^{63} \mathrm{See}$, in rare agreement, European Commission, A new EU Framework to strengthen the Rule of Law, $\operatorname{COM}(2014)$ 158, p. 5 and Council of the European Union, Opinion of the Legal Service: Commission's Communication on a new EU Framework to strengthen the Rule of Law: compatibility with the Treaties, 10296/14, para. 17; see further European Commission, Communication on Art. 7 of the Treaty on European Union. Respect for and promotion of the values on which the Union is based (15 October 2003), $\operatorname{COM(2003)~} 606$ final, p. 5; European Convention, Note from the Praesidium to the Convention, Draft of Articles 1 to 16 of the Constitutional Treaty (6 February 2003), CONV 528/ 03, p. 11; see further from literature e.g. M. Klamert and D. Kochenov, 'Article 2 TEU', in M. Kellerbauer et al. (eds.), The Treaties and the Charter of Fundamental Rights - A Commentary (Oxford University Press 2019) p. 22, 25; M. Hilf and F. Schorkopf, 'Art. 2 EUV', in Grabitz et al., supra n. 42, para. 18; C. Calliess, 'Art. 2 EUV', in Calliess and Ruffert, supra n. 43, para. 10; F. Schorkopf, Homogenität in der Europäischen Union (Duncker \& Humblot 2000) p. 69 ff.

${ }^{64}$ Such uncertainties are provoked first and foremost by the Commission itself, European Commission, supra n. 1, para. 1: "The Commission, beyond [!] its task to ensure the respect of EU law, is also responsible ... for guaranteeing the common values of the Union" (emphasis added); see e.g. C. Möllers and L. Schneider, Demokratiesicherung in der Europäischen Union (Mohr Siebeck 2018) p. 125 doubting that it is possible to derive 'legal obligation' from 'values'; similarly also E. Levits, 'Die Europäische Union als Wertegemeinschaft', in T. Jaeger (ed.), Europa 4.0 (Jan Sramek 2018) p. 239 at p. 263.
} 
the TEU. They are applied in legally determined procedures by public institutions (see Article 7, 13(1) or 49(1) TEU) and their disregard leads to sanctions, which are of a legal nature ${ }^{65}$ Indeed, the legal framing of the Union's values seems almost inevitable: the rule of law warrants that normative requirements enforced by public institutions are laid down in the form of law. Otherwise, the mechanisms of Article 7 or 49 TEU would provide purely political morality with public authority without making them subject to any constitutional checks and balances. ${ }^{66}$ That would be irreconcilable with the democratic rule of law. Therefore, Article 2 TEU values are necessarily part of EU law.

Certainly, the values enshrined in Article 2 are vague and open. ${ }^{67}$ In this sense, Article 2 TEU falls short of the criteria established by the original doctrine of direct effect which requires a Treaty provision to be precise, clear and unconditional. ${ }^{68}$ But as legal integration has deepened, these requirements have subsequently been relaxed. Today, the European Court of Justice's jurisprudence rests on the presumption, shared by national courts, that a provision of EU law is directly applicable by all courts. ${ }^{69}$ However, we do not claim that all values of Article 2 TEU are directly applicable as such. Rather, following the pertinent case law and a more cautious path, we suggest applying Article 2 TEU only in combination with other Treaty provisions. ${ }^{70}$

${ }^{65}$ T. Dumbrovsky, 'Beyond Voting Rights Suspension. Tailored Sanctions as Democracy Catalyst under Article 7 TEU', in A. Hatje and L. Tichy (eds.), Liability of Member States for the Violation of Fundamental Values of the European Union (EuR-Beiheft 1/2018) p. 203.

${ }^{66} \mathrm{On}$ the tension between Art. 7 TEU and the rule of law, see M. Niedobitek, 'Right and duty to pursue the "wrongdoer" and a possible abuse of Art. 7 TEU', in Hatje and Tichy, supra n. 65, p. $233,241$.

${ }^{67}$ In detail, see F. Hanschmann, Der Begriff der Homogenität in der Verfassungslehre und Europarechtswissenschaft (Springer 2008) p. 259 ff.; A. von Bogdandy, 'Founding Principles', in J. Bast and A. von Bogdandy (eds.), Principles of European Constitutional Law, $2^{\text {nd }}$ edn. (C.H. Beck, Hart, Nomos 2010) p. 11; D. Kochenov, "The Acquis and Its Principles. The Enforcement of the "Law" versus the Enforcement of "Values" in the EU', in Jakab and Kochenov, supra n. 53, p. 9; G. Toggenburg, 'Cultural Diversity at the Background of the European Debate on Values', in F. Palermo and G. Toggenburg (eds.), European Constitutional Values and Cultural Diversity (EURAC 2003) p. 9 at p. 13; on the need for a "non-controversial" and thus deliberately open set of values, see European Convention, supra n. 63.

${ }^{68}$ ECJ 5 February 1963, Case C-26/62, van Gend en Loos, EU:C:1963:1; on the state of the art, see P. Craig and G. De Búrca, EU Law, 6 ${ }^{\text {th }}$ edn. (Oxford University Press 2015) p. 192.

${ }^{69}$ In detail, see C. Wohlfahrt, Die Vermutung unmittelbarer Wirkung des Unionsrechts. Ein Plädoyer für die Aufgabe der Kriterien hinreichender Genauigkeit und Unbedingtheit (Springer 2016). There are exceptions to direct effect, but they are infrequent.

${ }^{70} \mathrm{~A}$ preliminary reference by a Bulgarian court gives an opportunity for clarifying these issues. The question is whether a member state court can 'directly invoke and directly apply Article 2 TEU' if it finds that a national law infringes upon a Union value; see reference by the District Court Vidin from 17 October 2018, Corporate Commercial Bank en liquidation, C-647/18. 
Indeed, to avoid applying Article 2 TEU directly, the initial Reverse Solange proposal built on the directly applicable Article $20 \mathrm{TFEU}$, as interpreted in the European Court of Justice's citizenship case law culminating in Ruiz Zambrano. In this decision, the Court established that Union citizens can invoke the 'substance' of their citizens' rights even in situations without any cross-border element. ${ }^{71}$ Our key idea was to interpret this 'substance' of citizenship as encompassing the 'essence' of human rights as enshrined in Article 2 TEU. ${ }^{72}$ Without directly relying on Article 2 TEU, the Court would indirectly be empowered to assess value compliance in the member states as part of the 'substance' of Union citizenship. This provided a path to judicially enforce the framers' decision laid down in Article 2 TEU while respecting the limits enshrined in Article 51(1) CFR.

At the time, we expected the Court to develop its citizenship case law further and thereby strengthen the jurisprudential 'hook' of the Reverse Solange doctrine. This did not happen. ${ }^{73}$ Rather, in what some scholars have even termed 'reactionary', ${ }^{74}$ the Court started construing the 'substance' of citizen's rights ${ }^{75}$ and their right to equal treatment restrictively. ${ }^{76}$

${ }^{71}$ ECJ 8 March 2011, Case C-34/09, Ruiz Zambrano, EU:C:2011:124, para. 42.

${ }^{72}$ For early proposals of linking fundamental rights to citizenship, see Advocate General Jacobs, 9 December 1992, Case C-168/91, Konstantinidis, para. 46; Advocate General Maduro, 12 September 2007, Case C-380/05, Centro Europa 7, paras. 16-22; Advocate General Colomer, 15 May 2008, Case C-228/07, Petersen, para. 27; see further S. O'Leary, 'The Relation Between Community Citizenship and the Protection of Fundamental Rights in Community Law', 32 CML Rev (1995) p. 540; D. O'Keeffe and A. Bavasso, 'Fundamental Rights and the European Citizen', in M. La Torre (ed.), European Citizenship: An Institutional Challenge (Kluwer Law 1998) p. 251; P. Eeckhout, 'The EU Charter of fundamental rights and the federal question', 39 CML Rev (2002) p. 945, 969 ff.; E. Spaventa, 'Seeing the wood despite the trees?', $45 C M L$ Rev (2008) p. 13, 39-44; M. Benlolo Carabot, Les Fondements Juridiques de la Citoyenneté (Bruylant 2008) p. 606, 614 ff.; critically, see M. van den Brink, 'EU citizenship and (fundamental) rights: Empirical, normative, and conceptual problems', 25 ELJ (2019) p. 21.

${ }^{73}$ For a strong critique of linking fundamental rights and citizenship, see K. Lenaerts and J.A. Gutiérrez-Fons, 'Epilogue on EU Citizenship: Hopes and Fears', in Kochenov, supra n. 53, p. 751 at p. 771 ff.; K. Lenaerts, 'EU Citizenship and Democracy', 7 New Journal of European Criminal Law (2016) p. 164 at p. 171; ibid., 'Linking EU Citizenship to Democracy', 11 Croatian Yearbook of European Law and Policy (2015) p. VII, XVI.

${ }^{74}$ E. Spaventa, 'Earned Citizenship - Understanding Union Citizenship through its Scope', in Kochenov, supra n. 53, p. 204, 205.

${ }^{75}$ ECJ 15 November 2011, Case C-256/11, Dereci and Others, EU:C:2011:734, para. 64; ECJ 5 May 2011, Case C-434/09, McCarthy, EU:C:2011:277; ECJ 8 May 2013, Case C-87/12, Ymeraga, EU:C:2013291, para. 37; ECJ 18 November 2012, Case C-40/11, Iida, EU:C:2012:69, para. 72; for a critical overview, see A. Tryfonidou, '(Further) Signs of a Turn of the Tide in the CJEU's Citizenship Jurisprudence', 20 Maastricht Journal (2013) p. 302; Spaventa, supra n. 74, p. 208-221.

${ }^{76}$ See e.g. ECJ 11 November 2014, Case C-333/13, Dano, EU:C:2014:2358; ECJ 15 September 2015, Case C-67/14, Alimanovic, EU:C:2015:597; ECJ 14 June 2016, Case C-308/14, Commission 
Accordingly, a strong jurisprudential 'hook' for the Reverse Solange doctrine must be found elsewhere. This is not difficult. In the following, we will show that the Court has been anything but inactive when it comes to operationalising Article 2 TEU.

As indicated, the Court recently started complementing the Union's traditional, rather functionally oriented rationale - consisting of autonomy, direct effect, primacy, and effet utile - with a more normative, truly constitutional, even axiological one: in Opinion 2/13, ASJP, Achmea, L.M., and Wightman, 'values' took centre stage. The reference to Article 2 TEU goes far beyond stylistic embellishment or mere 'constitutional iconography': ${ }^{77}$ what we are witnessing is the activation of Article 2 TEU values in the face of unexpected challenges. Today, the edifice of Union law rests on two pillars. The judgment in ASJP, in particular, represents a veritable stepping stone towards a 'Union of values' as important as van Gend en Loos and Costa/ENEL. To fend off the possible critique that it turns Article 2 TEU into the freestanding and unpredictable core of a centrifugal, member states-devouring constitution, the Court combines Article 2 TEU with other Treaty provisions. This leads to a much more predictable, but still powerful effect against illiberal tendencies through the 'mutual amplification' of the combined provisions. ${ }^{78}$

Yet, the expansive dynamic of 'mutual amplification' begs the question of whether such interpretation of EU provisions is within the law. However, to interpret any provision of a legal order consistently with other provisions, and in particular, in light of its basic principles, is part and parcel of the established method of systematic (or contextual) interpretation. ${ }^{79}$ Dynamic evolution of the

$\mathrm{v}$ the United Kingdom, EU:C:2016:436; D. Thym, 'Introduction: The Judicial Deconstruction of Union Citizenship', in D. Thym (ed.), Questioning Citizenship (Hart 2017) p. 1, 2 ff.; A. IliopolouPenot, 'Deconstructing the Former Edifice of Union Citizenship? The Alimanovic Judgement', 53 CML Rev (2016) p. 1007, 1015 ff.; A. Farahat, 'Solidarität und Inklusion: Umstrittene Dimensionen der Unionsbürgerschaft', 69 Die Öffentliche Verwaltung (2016) p. 45; S. Peers, 'Benefits for EU Citizens: A U-Turn by the Court of Justice', 74 The Cambridge Law Journal (2015) p. 195 at p. 196; for possible explanations, see M. Blauberger et al., 'ECJ Judges read the morning papers. Explaining the turnaround of European citizenship jurisprudence', 25 Journal of European Public Policy (2018) p. 1422; U. Šadl and M.R. Madsen, 'Did the financial crisis change European citizenship law? An analysis of citizenship rights adjudication before and after the financial crisis', 22 ELJ (2016) p. 40.

${ }^{77}$ To borrow an expression from J.H.H. Weiler, 'On the power of the Word: Europe's constitutional iconography', 3 ICON (2005) p. 173.

${ }^{78}$ For a first articulation of this idea, see L.D. Spieker, 'From Moral Values to Legal Obligations On How to Activate the Union's Common Values in the EU Rule of Law Crisis', MPIL Research Paper No. 2018-24, p. 25.

${ }^{79} \mathrm{~K}$. Lenaerts and J.A. Gutierrez-Fons, 'To Say What the Law of the EU is: Methods of Interpretation and the European Court of Justice', 20 Columbia Journal of European Law 
law is to be expected in a dynamic society, in particular from an apex court in a situation where its legal system is facing unprecedented challenges. An interpretation of EU law, including EU primary law, in light of the Article 2 TEU values is an accepted method of interpretation under Article 19(1)(2) TEU. How the Court operates is best demonstrated by its judgment in ASJP.

\section{Value-oriented interpretation}

ASJP concerned a salary reduction for Portuguese judges based on a memorandum of understanding concluded in the context of the Eurozone crisis. A Portuguese court asked the European Court of Justice whether the salary reduction violated the principle of judicial independence. The situation was beyond the ambit of the Charter (and especially Article $47 \mathrm{CFR})^{80}$ and presumably beyond the scope of EU law as traditionally perceived. In this sense, the Court could have declared the case inadmissible and $A S J P$ would have disappeared discreetly as another clarification of the meandering post-Akerberg Fransson case law. Yet, this is not what happened. The Court relied on Article 19(1)(2) TEU, which stipulates that 'member states shall provide remedies sufficient to ensure effective legal protection in the fields covered by Union law'. Effective legal protection presupposes, so says the Court, an independent judiciary. ${ }^{81}$ Read in this light, Article 19(1)(2) TEU contains a general obligation for the member states to ensure judicial independence 'in the fields covered by Union law'. ${ }^{82}$

These 'fields' are very broad. Importantly, the Court applies Article 19(1)(2) TEU 'irrespective of whether the Member States are implementing Union law, within the meaning of Article 51(1)' ${ }^{83}$ Article 19(1)(2) TEU thereby has a much broader scope of application than the Charter. ${ }^{84}$ While the Charter is limited to

(2014) p. 3, 17. In German, it is also called rechtsgrundsatzkonforme Auslegung, see S.A.E. Martens, Methodenlehre des Unionsrechts (Mohr Siebeck, 2013) p. 443.

${ }^{80}$ See the subsequent clarification in ECJ 24 June 2019, Case C-619/18 R, Commission v Poland, EU:C:2019:531, para. 51.

${ }^{81}$ For a thorough comparative analysis, see Seibert-Fohr, supra n. 30.

${ }^{82}$ Associação Sindical dos Juizes Portugueses, supra n. 15, para. 36.

${ }^{83}$ Ibid., para. 29 (emphasis added).

${ }^{84}$ See for this interpretation K. Lenaerts, 'On Judicial Independence and the Quest for National, Supranational and Transnational Justice', in G. Selvik et al. (eds.), The Art of Judicial Reasoning (Springer 2019) p. 155; T. von Danwitz, Values and the rule of law: Foundation of the European Union', Revue du droit de l'Union européenne (2018) (4) p. 263; Levits, supra n. 64, p. 268; see further L. Pech and S. Platon, 'Judicial Independence under threat: The Court of Justice to the rescue in the ASJP case', 55 CML Rev (2018) p. 1827 at p. 1837; M. Bonelli and M. Claes, 'Judicial serendipity: How Portuguese judges came to the rescue of the Polish judiciary', 14 EuConst (2018) p. 622 at p. 630-632; A. Miglio, 'Indipendenza del giudice, crisi dello stato di diritto e tutela giurisdizionale effettiva negli Stati membri dell'Unione europea', 12 Diritti Umani e Diritto Internazionale (2018) p. 421 at p. 426; T. Giegerich, 'Die Unabhängigkeit der Gerichte 
situations in which EU law is actually applying, ${ }^{85}$ Article 19(1)(2) TEU concerns all 'fields covered by Union law'. Stressing this semantic difference, Article 19 TEU, in the Court's reading, embraces any national court that at some point might use the preliminary ruling mechanism under Article 267 TFEU: '[T]hat mechanism may be activated only by a body responsible for applying EU law which satisfies, inter alia, that criterion of independence'. ${ }^{86}$ 'Responsible for applying EU law' includes all authorities that potentially find themselves applying it. ${ }^{87}$ Given the breadth of Union law today, it is hard to imagine that any member state court is outside those 'fields'. Thus, the entire national judiciary has to be in line with the EU value of the rule of law.

This seminal interpretation needs justification beyond its semantic compatibility with Article 19(1)(2) TEU. Indeed, ASJP can be doctrinally reconstructed along the lines of both a functional as well as the Union's axiological rationale.

The Court certainly employs the well-established effet utile rationale to justify the ample scope of Article 19(1)(2) TEU. First, the Court refers to the functioning of the preliminary reference procedure in Article 267 TFEU. National courts have an indispensable position in the effective and uniform application of EU law. ${ }^{88}$ As they are obliged to apply EU law over national law, they are also

als Strukturvorgabe der Unionsverfassung und ihr effektiver Schutz vor autoritären Versuchungen in den Mitgliedstaaten', 22 ZEuS (2019) p. 61 at p. 76. On the implications emerging from this statement, see L.D. Spieker, 'Commission v. Poland - A Stepping Stone Towards a Strong "Union of Values”?', Verfassungsblog, 30 May 2019.

${ }^{85}$ See e.g. M. Borowsky, 'Art. 51 - Anwendungsbereich', in Meyer, supra n. 47, para. 30b; D. Sarmiento, 'Who's Afraid of the Charter? The Court of Justice, National Courts and the New Framework of Fundamental Rights Protection in Europe', 50 CML Rev (2013) p. 1267 at p. 1279; T. von Danwitz and K. Paraschas, 'A Fresh Start for the Charter', 35 Fordham International Law Journal (2012) p. 1396 at p. 1409; C. Ladenburger, 'European Union Institutional Report', in J. Laffranque (ed.), Protection of Fundamental Rights Post-Lisbon. Reports of the XXV FIDE Congress (Tartu University Press 2012) p. 141 at p. 163; A. Rosas, 'When is the EU Charter of Fundamental Rights Applicable at National Level?', 19 Jurisprudence (2012) p. 1269 at p. 1284; M. Safjan, 'Fields of application of the Charter of Fundamental Rights and constitutional dialogues in the European Union', EUI Distinguished Lecture 2014/02, p. 4 ff.; S. Peers, 'The Rebirth of the EU's Charter of Fundamental Rights', 13 CYELS (2013) p. 283 at p. 298.

${ }^{86}$ Associação Sindical dos Juizes Portugueses, supra n. 15, para. 43 (emphasis added).

${ }^{87}$ See similarly the interpretation of von Danwitz, supra n. 84 .

${ }^{88}$ van Gend en Loos, supra n. 68; regarding the essential position of the preliminary reference procedure in the EU legal order, see further, Achmea, supra n. 21, para. 36; Accession of the EU to the ECHR, supra n. 19, para. 176; ECJ 8 March 2011, Opinion 1/09, Agreement creating a Unified Patent Litigation System, EU:C:2011:123, paras. 84-85. 
'Union courts' ${ }^{89}$ Such a system cannot work if member state courts are not independent: not without reason, a key criterion for launching preliminary references has been a court's independence. ${ }^{90}$

Second, the rationale behind Article 19(1)(2) TEU supports the Court's findings. ${ }^{91}$ There has been serious criticism that the barriers to individual legal protection under Article 263(4) TFEU are too high. ${ }^{92}$ Instead of relaxing these locus standi criteria, however, the drafters of the Lisbon Treaty opted for a strengthened decentralised judicial system based on the cooperation between the ECJ and member state courts. ${ }^{93}$ Individuals are generally not provided with 'supranational justice ${ }^{94}$ directly before the European Court of Justice but need to go through member state courts. The function of Article 19(1)(2) TEU is to ensure that this bifurcated judicial system works and that no protection gaps open within the EU legal space. ${ }^{95}$ This implies supranational standards regarding the

${ }^{89}$ See ECJ 9 March 1978, Case C-106/77, Simmenthal, EU:C:1978:49; ECJ 23 April 1986, Case C-294/83, Les Verts, EU:C:1986:166; more recently Agreement creating a Unified Patent Litigation System, supra n. 88, para. 80; see on this A. Rosas, 'The National Judge as EU Judge', in P. Cardonnel et al. (eds.), Constitutionalising the EU Judicial System (Hart Publishing 2012) p. 105; R. Baratta, 'National Courts as "Guardians" and "Ordinary Courts" of EU Law: Opinion 1/09 of the ECJ', 38 Legal Issues of Economic Integration (2011) p. 297.

${ }^{90}$ For cases, in which the ECJ actually assessed the independence of the referring entity, see ECJ 6 October 2015, Case C-203/14, Consorci Sanitari del Maresme, EU:C:2015:664, para. 19; ECJ 9 October 2014, Case C-222/13, TDC, EU:C:2014:2265, paras. 28-36; ECJ 17 July 2014, Case C-58/13 and C-59/13, Torresi, EU:C:2014:2088, paras. 18-25; ECJ 14 May 2008, Case C-109/ 07, Pilato, EU:C:2008:274, paras. 21-30; ECJ 19 September 2006, Case C-506/04, Wilson, EU: C:2006:587; ECJ 31 May 2005, Case C-53/03, Syfait, EU:C:2005:333, paras. 29, 31; ECJ 30 May 2002, Case C-516/99, Schmid, EU:C:2002:313, paras. 35; ECJ 6 July 2000, Case C-407/98, Abrahamsson and Anderson, EU:C:2000:367, paras. 29-37; ECJ 4 February 1999, Case C-103/ 97, Köllensperger and Atzwanger, EU:C:1999:52, paras. 19-24; ECJ 17 September 1997, Case C-54/96, Dorsch Consult, EU:C:1997:413, paras. 34-36; more generally, see Broberg and Fenger, supra n. 42, p. 62 ff.

${ }^{91}$ M. Krajewski, 'Who is Afraid of the European Council? The Court of Justice's Cautious Approach to Independence of Domestic Judges', 14 EuConst (2018) p. 792 at p. 808 ff.; Pech and Platon, supra n. 84, p. 1835-1836.

${ }^{92}$ Opinion of Advocate General Jacobs, 21 March 2002, Case C-50/00 P, Unión de Pequeños Agricultores v Council, paras. 36-49.

${ }^{93} \mathrm{~T}$. Tridimas, 'The Court of Justice in the European Union', in R. Schütze and T. Tridimas (eds.), Oxford Principles of European Union Law (Oxford University Press 2018) p. 581 at p. 582-584; ibid., 'Bifurcated Justice: The Dual Character of Judicial Protection in EU Law', in A. Rosas et al. (eds.), The Court of Justice and the Construction of Europe (Asser Press 2013) p. 367.

${ }^{94}$ Lenaerts, supra n. 84 , p. 158.

${ }^{95}$ See K. Lenaerts, 'The Rule of Law and Coherence of the Judicial System of the European Union’, 44 CML Rev (2007) p. 1625 at p. 1629-1630. 
national judiciary, its remedies and procedures. ${ }^{96}$ Read in this functionalist light, one might consider the ASJP decision as important, but conventional - more 'business as usual' than a 'tectonic shift'. ${ }^{97}$

Yet, such a reading overlooks the Court's additional axiological justification for the ample scope of Article 19(1)(2). The Court states that

'Article 19 TEU $[\ldots]$ gives concrete expression to the value of the rule of law stated in Article 2, ${ }^{98}$

The Court interprets Article 19 TEU in light of the values enshrined in Article 2 (in this case the rule of law) similar to how the original Reverse Solange doctrine interpreted Article 20 TFEU. Through this linkage, the vague Article 2 TEU becomes relevant. It is indirectly applied via a norm containing a specific obligation for the member states (Article 19 TEU). ${ }^{99}$ The Court avoids the possibly contentious step of applying Article $2 \mathrm{TEU}$ as a freestanding provision. ${ }^{100}$ The genius is in combining two provisions. ${ }^{101}$ The values in Article 2 gain legal effect via a value-oriented interpretation of a directly applicable provision, which, in turn, is read in an expansive way justified by the value in question. How does this work concretely?

At first glance Article 2's scope would depend on the scope of its operationalising provision. If a value was operationalised by Article 19(1)(2) TEU, it would be limited to 'fields covered by Union law'. Hence, it seems that this operation does not help to protect the role of Article 2 for any national measure. ${ }^{102}$ Yet, in ASJP the Court derives standards of judicial independence from Article 19(1)(2) TEU

\footnotetext{
${ }^{96}$ See T. Jaeger, 'Gerichtsorganisation und EU-Recht: Eine Standortbestimmung', 53 EuR (2018) p. 611 at p. $615 \mathrm{ff}$.

${ }^{97}$ S. Schill and C. Krenn, 'Art. 4 EUV', in Grabitz et al., supra n. 42, in para. 102 ff.; Jaeger, supra n. 96 , p. $615 \mathrm{ff}$.

${ }^{98}$ Associação Sindical dos Juizes Portugueses, supra n. 15, para. 32 (emphasis added).

${ }^{99}$ von Bogdandy et al., supra n. 54, p. 985.

${ }^{100}$ For an approach relying directly on Art. 2 TEU see C. Hillion, 'Overseeing the Rule of Law in the EU: Legal Mandate and Means', in C. Closa and D. Kochenov (eds.), Reinforcing Rule of Law Oversight in the European Union (Cambridge University Press 2016) p. 59 at p. 66 ff.; similarly K.L. Scheppele, 'Enforcing the Basic Principles of EU Law through Systemic Infringement Actions', in Closa and Kochenov, ibid., p. 105; V. Skouris, Demokratie und Rechtsstaat. Europäische Union in der Krise? (C.H. Beck 2018) p. 50.

${ }^{101}$ For first sketches, see C. Closa and D. Kochenov, 'Reinforcing the Rule of Law Oversight in the European Union: Key Options', in W. Schroeder (ed.), Strengthening the Rule of Law in Europe (Hart Publishing 2016) p. 173 at p. 182-184; L. Pech et al., An EU Mechanism on Democracy, the Rule of Law and Fundamental Rights (European Parliament, EPRS 2016) p. 198; E. Cannizzaro, 'I ruolo della Corte di giustizia nella tutela dei valori dell'Unione europea', in Liber Amicorum Antonio Tizzano (Giappichelli 2018) p. 159.

${ }^{102}$ See supra n. 63.
} 
which are likely to apply to any member state court. A value-oriented interpretation has the effect of justifying such a broad and demanding reading. This is the effect of a 'mutual amplification': Article 2 TEU becomes judicially applicable through the systematic, value-oriented interpretation of the specific provision (here Article 19(1)(2) TEU). At the same time, the value-oriented interpretation 'charges' the specific provision feeding on the general and foundational nature of Article 2. This 'charging' effect also pertains to the specific provision's scope.

In this relationship of 'mutual amplification', both provisions reinforce each other. As such, Article 2 TEU and its specific 'carrier' can create legal obligations for the member states in what would otherwise be considered 'purely internal situations'. ${ }^{103}$ Of course, such an interpretation cannot and does not a priori establish the judicial applicability of any Article 2 TEU value to any national measure. However, it shows how the judicial applicability of EU values can be established in a specific case. All depends on finding a specific provision giving expression to a value enshrined in Article 2 TEU.

The Court reaffirmed this intrinsic link between Article 2 TEU and a specific provision of EU law in Commission v Poland. It stressed that 'Article 19 TEU .... gives concrete expression to the value of the rule of law affirmed in Article 2 TEU'104 and that the respective 'EU law that implements those values' ${ }^{\prime 05}$ has to be respected by the member states. Unlike in $A S J P$, the Court found a violation of Article 19(1)(2) TEU operationalising Article 2 TEU. In this sense, both judgments can serve as a prime example of the Court's 'stone by stone' approach. ${ }^{106}$ The Court laid the groundwork and outlined the general idea of operationalising Article 2 TEU values in ASJP. This judgment could thus be regarded as the 'founding stone' of an emerging line of jurisprudence. However, the Court carefully refrained from finding any violation in the case. Instead, ASJP served as a stepping stone for the infringement proceedings against Poland.

${ }^{103}$ See Spieker, supra n. 78 , p. 25.

${ }^{104}$ Commission v Poland, supra n. 80, para. 47; Opinion of Advocate General Tanchev, 20 June 2019, Case C-192/18, Commission v Poland, para. 71: 'the second subparagraph of Article 19(1) TEU, a specific manifestation on the foundational values reflected in Article 2 TEU' (emphasis added); Opinion of Advocate General Tanchev, 27 June 2019, Cases C-585/18, C-624/18 \& C-625/18, Krajowa Rada Sadownictwa (Indépendance de la chambre disciplinaire de la Cour suprême, para. 77.

${ }^{105}$ Commission v Poland, supra n. 80, para. 43.

${ }^{106} \mathrm{~K}$. Lenaerts, 'The Court's Outer and Inner Selves: Exploring the External and Internal Legitimacy of the European Court of Justice', in M. Adams et al. (eds.), Judging Europe's Judges (Hart Publishing 2013) p. 13 at p. 46; see also the 'three-steps-forward-one-step-backward-andeverybody-happy technique' in $H$. Rasmussen, 'On Legal Normative Dynamics and Jurisdictional Dialogue in the Field of Community General Principles of Law', in U. Bernitz and J. Nergelius (eds.), General Principles of European Community Law (Kluwer Law 2000) p. 35 at p. 40. 
Commission v Poland makes it very clear that the Court is willing to scrutinise and sanction member state actions under the newly activated Article 2 TEU.

Values and the essence of Charter rights

ASJP does not address fundamental rights. Yet, the mechanism of mutual amplification also works with regard to fundamental rights, be it via the value of 'respect for human rights' or via the 'rule of law' value, as the L.M. case demonstrates. In this case concerning a European Arrest Warrant issued by Poland, an Irish court asked the European Court of Justice to interpret the reasons justifying a denial of execution when judicial independence in the issuing country is at risk. The Court applied its two-pronged Aranyosi test: First, the Irish judge had to determine whether there were generalised deficiencies of judicial independence in Poland, and second, whether such deficiencies triggered the risk of an individual fundamental rights violation (Article 47 CFR) in the pertinent domestic criminal proceedings. ${ }^{107}$

Although the issue of surrender is clearly within the scope of Union law as defined by Article 51(1) CFR, this is not the case for what is scrutinised under the Aranyosi test. Neither the Polish judicial reforms nor the specific domestic criminal proceedings show an evident link to EU law. Indeed, the general reforms and the concrete criminal case are even more remote than the subject matter of $A S J P$ : a Polish criminal proceeding against a Polish citizen for possible criminal offences committed in Poland is hardly covered by Article 51 CFR as it stands. ${ }^{108}$ Nevertheless, the European Court of Justice instructed the Irish court that it must, under EU law, review the Polish judicial reform and its impact on the case at hand. ${ }^{109}$

${ }^{107}$ Minister for Justice and Equality, supra n. 15, para. 60, on the judgment, see the symposium 'The CJEU's Deficiencies Judgment' on Verfassungsblog, at 〈verfassungsblog.de/category/themen/ after-celmer/ $\rangle$, visited 21 August 2019.

${ }^{108}$ On the interpretation of Article 51(1) CFR, see ECJ 26 February 2013, Case C-617/10, Åkerberg Fransson, EU:C:2013:105, para. 18 ff.; for an attempt to systematise the meandering post-Fransson case law, see Advocate General Bobek, 7 September 2017, Case C-298/16, Ispas, para. $29 \mathrm{ff}$.; for a comprehensive account of the case law post-CFR, see N. Lazzerini, La Carta dei Diritti Fondamentali dell'Unione Europea. I Limiti di Applicazione (FrancoAngeli 2018) p. 183 ff.; R. Stotz, 'Aktuelle Rechtsprechung zur EU-Charta der Grundrechte', 20 ZEuS (2017) p. 259; Dougan, supra n. 62; Sarmiento, supra n. 85; E. Hancox, 'The meaning of "implementing" EU law under Article 51(1) of the Charter: Åkerberg Fransson', 50 CML Rev (2013) p. 1411.

${ }^{109}$ Being a preliminary ruling procedure, the ECJ refrained from applying the law itself; on this see von Bogdandy et al., supra n. 54, p. 992. However, the Court can also fully assess the conditions in the issuing member state, see ECJ 21 December 2011, Cases C-411/10 and C-493/10, N.S., EU: C:2011:865; ECJ 25 July 2018, Case C-220/18 PPU, Generalstaatsanwaltschaft (Conditions de détention en Hongrie), EU:C:2018:589. 
Some scholars read these instructions as a narrow issue referring to the specificities of the European Arrest Warrant Framework and other mutual recognition regimes. ${ }^{110}$ We propose reading L.M. as a much broader follow-up to ASJP. As such, the Court paved the way for assessing the Polish reforms and criminal proceedings under Article $2 \mathrm{TEU}$ in combination with the essence of the fundamental right laid down in Article 47 CFR. In the central passage, the European Court of Justice stated that

judicial independence forms part of the essence of the fundamental right to a fair trial, a right which is of cardinal importance as a guarantee ... that the values common to the Member States set out in Article 2 TEU, in particular the value of the rule of law, will be safeguarded. ${ }^{111}$

As before in $A S J P$, the Court established a nexus between a specific provision of EU law (the 'essence' of Article 47 CFR) and the Union values as enshrined in Article 2, more precisely the value of the rule of law. ${ }^{112}$ Therefore, the logic of 'mutual amplification' also applies to Charter rights in so as far as they give expression to the values in Article 2 TEU.

\section{Questions of competence}

One cannot deny that this 'mutual amplification' through systematic interpretation expands rather than limits the reach of EU law. For that reason, it must not only be methodologically sound but also conform with the order of competences. Indeed, there is an argument to be made that there might not be any competence for the courts and in particular the European Court of Justice to assess whether member states respect Article 2 TEU. Koen Lenaerts stresses that the Treaties have entrusted the EU's political institutions, thus not the European Court of Justice, with the task of monitoring whether 'there is a clear risk of a serious breach by a Member State of the values referred to in Article 2'. In fact, Article 269 TFEU limits the Court's role to verifying the procedural stipulations laid down in Article 7 TEU. ${ }^{113}$ Any interpretation that puts the European Court of Justice in the position which Article 7 TEU attributes to political institutions faces a high argumentative burden. For example, the Court cannot suspend a member state's rights. ${ }^{114}$

\footnotetext{
${ }^{110}$ See also with regard to other mutual recognition regimes (e.g. Dublin), Canor, supra n. 58, p. 395-396.

${ }^{111}$ Minister for Justice and Equality, supra n. 15, para. 48.

${ }^{112} \mathrm{On}$ this nexus, see also M. Wendel, 'Mutual Trust, Essence and Federalism - Between Consolidating and Fragmenting the Area of Freedom, Security and Justice after LM', 15 EuConst (2019) p. 17 at p. 27-29.

${ }^{113}$ See Lenaerts and Gutiérrez-Fons, supra n. 73, p. 774.

${ }^{114}$ See e.g. Minister for Justice and Equality, supra n. 15, para. $70 \mathrm{ff}$.
} 
However, this argument does not preclude Article 2 TEU from playing a role when the Court discharges its mandate to ensure that 'the law is observed' (Article 19(1)(1) TEU). ${ }^{15}$ While the former Treaties have kept the EU's foundational principles out of the Court's reach, ${ }^{116}$ the Lisbon Treaty does not contain any such limitation with regard to Article 2 TEU. Article 269 TFEU is an exception to the European Court of Justice's general competence under Article 19(1)(1) TEU, which, being an exception, has to be interpreted narrowly. Moreover, since van Gend en Loos, the European Court of Justice has allowed individual legal action to complement action by the political institutions. Today, this judicial innovation is generally recognised to be at the heart of the European legal edifice.

Finally, the political Article 7 TEU and the judicial Article 258/267 TFEU procedures have different objects and consequences. Article 7 TEU concentrates on a political situation and ultima ratio entails the suspension of member states' rights eventually leading to a sort of 'quarantine'. ${ }^{117}$ In contrast, the Court adjudicates individual cases and its sanctioning powers are limited to Article 260 TFEU (penalty payments). Thus, there is no identity between the judicial and the political procedures imposing the latter's exclusivity. All this justifies the Court's recent path in ASJP and L.M., which applies Article 2 TEU in combination with more specific provisions. ${ }^{118}$

${ }^{115}$ See e.g. M. Schmidt and P. Bogdanowicz, 'The Infringement Procedure in the Rule of Law Crisis: How to Make Effective Use of Art. 258 TFEU', 55 CML Rev (2018) p. 1061 at p. 1069-1073; Hillion, supra n. 100, p. 71-73; Kochenov, supra n. 67, p. 11; J-W Müller, 'Should the EU Protect Democracy and the Rule of Law inside Member States?', 21 ELJ (2015) p. 141 at p. 146; Scheppele, supra n. 100, p. 114; M. Waelbroeck and P. Oliver, 'La Crise de l'État de Droit dans l'Union Européenne: Que Faire?', 26 Cahiers de droit européen (2017) p. 299 at p. 335; Skouris, supra n. 100, p. 50 ff.; Hilf and Schorkopf, supra n. 63, para. 46; C. Franzius, 'Der Kampf um Demokratie in Polen und Ungarn', 71 Die Öffentliche Verwaltung (2018) p. 381 at p. 386; for an exclusion of Art. 2 TEU from the Court's jurisdiction, Levits, supra n. 64, p. 262; S.F. Nicolisi, 'The Contribution of the Court of Justice to the Codification of the Founding Values of the European Union', 51 Revista de Derecho Comunitario Europeo (2015) p. 613 at p. 643; B. Martenczuk, Art. 7 EUV und der Rechtsstaatsrahmen als Instrument der Wahrung der Grundwerte der Union', in S. Kadelbach (ed.), Verfassungskrisen in der Europäischen Union (Nomos 2018) p. 41 at p. 46 ff.; on Art. 269 TFEU as 'unconstitutional constitutional law', see Giegerich, supra n. 84, p. 80.

${ }^{116}$ According to Art. 46(d) TEU (Nice version) the ECJ was only competent for what was then Art. 6(2) TEU (Nice) but not for the 'principles' laid down in Art. 6(1) TEU (Nice). But even then, those principles were relevant, see Kadi, supra n. 59, para. 303.

${ }^{117} \mathrm{~F}$. Schorkopf, 'Wertesicherung in der Europäischen Union. Prävention, Quarantäne und Aufsicht als Bausteine eines Rechts der Verfassungskrise?', 51 EuR (2016) p. 147.

${ }^{118}$ See especially the Opinion of Advocate General Tanchev in the recent infringement procedure against Poland, see Opinion of 11 April 2019, Case C-619/18 R, Commission v Poland, para. 50. 


\section{Maintaining the federal balance}

The courts in the EU can apply Article 2 TEU in combination with specific provisions of EU law. Fundamental rights are thereby extended beyond the confines of Article 51(1) CFR. Such application might bring about a massive power shift to the Union and uproot the balance established by the Treaties between the Union and its member states to the detriment of national autonomy, identity, and diversity.

This should be avoided, not least because it would threaten the Union itself as vigorous national countermeasures would be likely. Many are already concerned that European fundamental rights might expand to the point of suffocating the member states, derail national achievements and even bring about an unwanted European federal state. ${ }^{119}$ Article 51(1) CFR is a testimony to this concern. Although its interpretation and application do not fulfil all the hopes set into the Charter, ${ }^{120}$ the Court respects that there are limits. ${ }^{121}$ It is not without very good reason that the Charter does not cover all domestic laws, measures, and decisions. Any response to illiberal tendencies has to respond to this concern.

Limiting elements are needed. To this end, Article 2 TEU should be interpreted narrowly, as mainly demarcating red lines which are transgressed with regard to fundamental rights only when their 'essence' is concerned. Further, the courts should exercise their respective competences in the form of a Solange presumption.

High standards for violating Article 2 TEU: crossing red lines

There is one important difference between the Reverse Solange doctrine under EU law and the doctrine's original articulation by the Federal German Constitutional Court under German law. The German court requires that the essential standards of legal order B (EU law) are 'equivalent', ${ }^{122}$ 'substantially similar' ${ }^{123}$ or 'essentially

\footnotetext{
${ }^{119}$ For the centralising potential of fundamental rights, see generally J.A. Frowein et al., 'The Protection of Fundamental Human Rights as a Vehicle of Integration', in M. Cappelletti et al. (eds.), Integration Through Law, Vol I/3 (Nomos 1986) p. 231; with regard to EU fundamental rights, see P.M. Huber, 'Unitarisierung durch Gemeinschaftsgrundrechte - Zur Überprüfungsbedürftigkeit der ERT-Rechtsprechung', 43 EuR (2008) p. 190; Eeckhout, supra n. 72; A. von Bogdandy, 'Zweierlei Verfassungsrecht', 39 Der Staat (2000) p. 163 at p. 168, 183.

${ }^{120}$ For a critique, see P.M. Huber, 'Auslegung und Anwendung der Charta der Grundrechte', 64 Neue Juristische Wochenschrift (2011) p. 2385; ibid., 'Grundrechtsschutz in Europa - Vermehrung, Verunsicherung, Kohärenz', in G. Biaggini et al. (eds.), Festschrift für Daniel Thürer (Nomos 2015) p. 305.

${ }^{121}$ See supra n. 108.

${ }^{122}$ See similarly, Bosphorus v Ireland, supra n. 60, para. 155.

${ }^{123}$ Solange II, supra $\mathrm{n} .56$.
} 
comparable ${ }^{\prime 24}$ to legal order A (German law). The Reverse Solange doctrine is less demanding. It requires the respect of essential standards, since Article 2 TEU only aims at safeguarding essential values. ${ }^{125}$ Any other interpretation would infringe upon the legally guaranteed constitutional autonomy of the member states (and thus the 'federal balance') and ignore the actually existing constitutional pluralism in the Union.

First, Article 2 TEU cannot demand 'equivalent' standards from member states, as such an interpretation cannot be squared with either Articles 4(2) and 5(1) TEU or Article 51(1) CFR. This would run up against the member states' constitutional autonomy and the federal equilibrium guaranteed by the Treaties. This becomes quite apparent when considering fundamental rights: relying only on the essentials avoids a breach of Article 51(1) CFR. The Charter, with its full fundamental right acquis, remains solely applicable to member states 'when they are implementing Union law'.

Second, Article 2 TEU can hardly force detailed obligations upon the member states' legal orders. The Treaties protect diversity among the national constitutions: the republics and monarchies, parliamentary and semi-presidential systems, strong and weak parliaments, competitive and consensual democracies, strong and weak political party systems, strong and weak social institutions, unitary and federal systems, strong, weak or absent constitutional courts, diverse and perhaps even incompatible systems of judicial independence, significant divergences in the content and level of protection of fundamental rights, not least Ottoman, Catholic, Protestant, secular, socialist, anarcho-syndicalist, postcolonial and statist constitutional traditions. ${ }^{126}$

As Werner Schroeder puts it, Article 2 TEU does 'not aim at the existence of uniform principles and rules, but solely at the observing of European minimum standards. ${ }^{127}$ Such an interpretation is confirmed by the vagueness of the values, the intent of the Treaty drafters ${ }^{128}$ as well as the very high procedural and substantial thresholds of the Article 7 TEU procedure. Article 2 TEU was not created for 'light-minded every-day use' ${ }^{129}$ and should be limited to essential values.

\footnotetext{
${ }^{124}$ Bananenmarkt, supra n. 56, para. 57.

${ }^{125}$ See von Bogdandy et al., supra n. 53, p. 510; Hilf and Schorkopf, supra n. 63, para. 36.

${ }^{126}$ See similarly Hanschmann, supra n. 67, p. $248 \mathrm{ff}$.

${ }^{127} \mathrm{~W}$. Schroeder, 'The European Union and the Rule of Law - State of Affairs and Ways of Strengthening', in Schroeder, supra n. 101, p. 3 at p. 11.

${ }^{128}$ European Convention, supra n. 63, p.11: 'This Article can thus only contain a hard core of values meeting two criteria at once: on the one hand, they must be so fundamental that they lie at the very heart of a peaceful society practicing tolerance, justice and solidarity; on the other hand, they must have a clear non-controversial legal basis so that the member states can discern the obligations resulting therefrom which are subject to sanction' (emphasis added).

${ }^{129}$ Schmidt and Bogdanowicz, supra n. 115, p. 1081.
} 
What does it mean to restrict Article 2 TEU to essential values? On a conceptual level, we propose to interpret Article 2 TEU as primarily establishing 'red lines'. ${ }^{130}$ Article 2 TEU should be read as negatively determining what is not allowed, without positively determining how it should be instead. The central aspect is what cannot be done. With regard to fundamental rights, such a red line approach concentrates on their 'essence'. This notion relies on long-standing jurisprudence and widespread recognition. It can be found in Article 52(1) CFR and numerous member state constitutions. ${ }^{131}$

In this sense, the European Court of Justice states in its seminal Aranyosi judgment that it is the risk of the violation of an absolute right which undermines the basis for mutual trust between member states. ${ }^{132}$ Mutual trust is based 'on the fundamental premiss that each Member State shares with all the other Member States ... a set of common values on which the EU is founded, as stated in Article 2 TEU'. ${ }^{133}$ If violating absolute rights unsettles the presumption of mutual trust, these rights conversely fall under Article 2 TEU. In L.M., the European Court of Justice extended these findings to the essence of rights, in the case at hand of the right to a fair trial under Article 47 CFR. ${ }^{134}$

Therefore, both absolute rights as well as the essence of other fundamental rights constitute red lines protected by Article 2 TEU. It is only in such extreme situations that an individual can rely on Article 2 TEU to seek redress before national courts, and the European Court of Justice can adjudicate on the issue, be it within preliminary ruling or infringements proceedings.

\footnotetext{
${ }^{130}$ See von Bogdandy et al., supra n. 54; see for similar narrow conceptions A. Voßkuhle, The Idea of the European Community of Values (Thyssen Lecture 2017) p. 108 at p. 117 ('essential content'); G. Toggenburg and J. Grimheden, 'Managing the Rule of Law in a Heterogeneous Context: A Fundamental Rights Perspective on Ways Forward', in Schroeder, supra n. 101, p. 221 ('minimum constitutional cohesion'); T.-P. Holterhus and D. Kornack, 'Die materielle Struktur der Unionsgrundwerte. Auslegung und Anwendung des Art. 2 EUV im Lichte aktueller Entwicklungen in Rumänien und Ungarn', 41 EuGRZ (2014) p. 389 ('Kern').

${ }^{131}$ See, in more detail, von Bogdandy et al., supra n. 53, p. $510 \mathrm{ff}$.; on the notion of 'essence', see further M. Brkan, 'The Concept of Essence of Fundamental Rights in the EU Legal Order: Peeling the Onion to its Core', 14 EuConst (2018) p. 332; more cautiously, see Wendel, supra n. 112, p. 32-35; sceptical, see M. Cornils, 'Schrankendogmatik', in Grabenwarter, supra n. 62, $\$ 5$ para. 104 ff.; M. Hilf, 'Die Schranken der EU Grundrechte', in D. Merten and H.J. Papier (eds.), Handbuch der Grundrechte, Vol VI/1: Europäische Grundrechte I (C.F. Müller 2010) $\$ 164$ para. 62 .

${ }^{132}$ ECJ 5 April 2016, Cases C-404/15 and C-659/15 PPU, Aranyosi and Căldăraru, EU: C:2016:198, para. $82 \mathrm{ff}$.

${ }^{133}$ See Accession of the EU to the ECHR, supra n. 19, para. 168; Minister for Justice and Equality, supra n. 15, para. 35; Achmea, supra n. 21, para. 34.

${ }^{134}$ Minister for Justice and Equality, supra n. 15, paras. 59-60.
} 


\section{The Solange presumption}

Most Solange doctrines, including Reverse Solange, establish the presumption in legal order A that acts emanating from legal order B comply with A's standards. This facilitates successful cooperation, a towering objective of Union law. Under EU law, this presumption flows from the principle of mutual trust. As a 'constitutional principle', perhaps even the Union's 'raison d'être', ${ }^{135}$ it demands that all member states are deemed to comply with Article $2 \mathrm{TEU}$. A common legal space, as well as majority voting in the Council, create a situation of 'mutual vulnerability'. ${ }^{136}$ Accepting such mutual vulnerabilities is only possible if it can be presumed that all member states truly comply with basic standards.

Initially, mutual trust only applied horizontally between the member states. ${ }^{137}$ One could argue that 'because Brussels can mistrust Member States, Member States can ... trust each other'. ${ }^{138}$ This would exclude mutual trust in the vertical relationship between the Union (more precisely: the European Court of Justice) and the member states. However, this misreads mutual trust, which has a much broader scope, involving cooperation between all public institutions in the European legal space. The principle of mutual loyalty, which can be seen as the origin of mutual trust, ${ }^{139}$ expressly extends to Union institutions. ${ }^{140}$ The principle of trust cuts both ways: it supports the presumption that all public

${ }^{135}$ N.S., supra n. 109; see further Melloni, supra n. 62, paras. 37 and 63; Accession of the EU to the ECHR, supra n. 19, para. 191.

${ }^{136}$ For a sophisticated analysis of such effects, see A. Somek, 'The Argument from Transnational Effects I: Representing Outsiders through Freedom of Movement', 16 ELJ (2010) p. 315.

${ }^{137}$ See the wording in Associação Sindical dos Juizes Portugueses, supra n. 15, para. 30; Minister for Justice and Equality, supra n. 15, para. 35.

${ }^{138}$ Müller, supra n. 115 , p. 145.

${ }^{139} \mathrm{~F}$. Meyer, 'Der Grundsatz gegenseitigen Vertrauens - Konzeptualisierung und Zukunftsperspektiven eines neuen Verfassungsprinzips', 52 EuR (2017) p. 163 at p. 179 ff.; M. Fartunova, 'La coopération loyale vue sous le prisme de la reconnaissance mutuelle: quelques réflexions sur les fondements de la construction européenne', 52 Cahiers de droit européen (2016) p. 193; C. Janssens, The Principle of Mutual Recognition in EU Law (Oxford University Press 2013) p. $151 \mathrm{ff}$.; on the intrinsic link between the principles of mutual trust and loyalty, see S. Prechal, 'Mutual Trust Before the Court of Justice of the European Union', 2 European Papers (2017) p. 75 at p. 90-92; D. Gerard, 'Mutual Trust as Constitutionalism?', in E. Brouwer and D. Gerard (eds.), Mapping Mutual Trust: Understanding and Framing the Role of Mutual Trust in EU Law (EUI 2016) p. 69 at p. 76; see also K. Lenaerts, 'La vie après l'avis: Exploring the principle of mutual (yet not blind) trust', 54 CML Rev (2017) p. 805 at p. 807 who derives it from the principle of equality between the member states; for a theoretical underpinning, see T. Wischmeyer, 'Generating Trust Through Law? Judicial Cooperation in the European Union and the "Principle of Mutual Trust", 17 German Law Journal (2017) p. 339 at p. 347; M. Schwarz, 'Let's talk about trust, baby! Theorizing trust and mutual recognition in the EU's area of freedom, security and justice', 24 ELJ (2018) p. 124.

${ }^{140} \mathrm{ECJ} 16$ October 2003, Case C-339/00, Ireland v Commission, EU:C:2003:545, para. 72: 'the duty to cooperate in good faith is, by its very nature, reciprocal'. 
institutions live up to the basic standards, but it also calls for credible monitoring and protective instruments. EU law does not require 'blind trust'. ${ }^{141}$

How to mediate between these two opposing objectives? It seems that the concept of systemic deficiency might prove useful. ${ }^{142}$ Indeed, the other denomination of the L.M. case is 'deficiencies in the system of justice'. ${ }^{143}$ It is not only a well-embedded concept in the Court's case law ${ }^{144}$ but also used by many other institutions for situations where European values are at stake. ${ }^{145}$ Accordingly, it is easier to rebut the presumption when the case at hand is part of a regular and widespread practice or when it is commanded by the highest authority as an expression of a political agenda. In other instances, for the sake of its federal balance, the European legal order refrains from activating Article 2 TEU values and relies on the many other instruments available, including recourse to the European Court of Human Rights, to protect human and fundamental rights.

\section{SUMMING UP}

Looking at the recent developments through the prism of the Reverse Solange doctrine, we see that much has changed. In 2012, the idea of bringing Article 2

${ }^{141}$ Lenaerts, supra n. 139.

${ }^{142}$ von Bogdandy et al., supra n. 53, p. 513; in more detail concerning systemic deficiencies in the rule of law, see A. von Bogdandy and M. Ioannidis, 'Systemic deficiency in the rule of law: What it is, what has been done, what can be done', 51 CML Rev (2014) p. 59; on the importance of this concept, see also Wendel, supra n. 112, p. 37-40.

${ }^{143}$ See ECJ, Press Release No. 113/18, at (curia.europa.eu/jcms/upload/docs/application/pdf/ 2018-07/cp180113en.pdf), visited 21 August 2019.

${ }^{144}$ See e.g. N.S., supra n. 109, paras. 86, 89; see further Minister for Justice and Equality, supra n. 15, para. 61; Aranyosi and Căldăraru, supra n. 132, para. 89; Generalstaatsanwaltschaft (Conditions de détention en Hongrie), supra n. 109, para. 60; see, however, the recent judgments in ECJ 19 March 2019, Case C-163/17, Jawo, EU:C:2019:218, para. 87 ff. and ECJ 19 March 2019, Case C-297/ 17, Ibrahim, EU:C:2019:219, para. $87 \mathrm{ff}$. where the Court seems to depart from that notion.

${ }^{145}$ With regard to Art. 7(2) TEU ('serious and persistent breach'), see European Commission, supra n. 63, para. 4.1; with regard to rule of law conditionality in the EU budget, see European Commission, Proposal for a Regulation of the European Parliament and of the Council on the protection of the Union's budget in case of generalised deficiencies as regards the rule of law in the member states, COM/2018/324 final, Art. 2(b): "generalised deficiency as regards the rule of law' means a widespread or recurrent practice or omission, or measure by public authorities which affects the rule of law"; see also the pilot judgments in the Council of Europe, J. Czepek, 'The Application of the Pilot Judgment Procedure and Other Forms of Handling Large-Scale Dysfunctions in the Case Law of the European Court of Human Rights', 20 International Community Law Review (2018) p. 347; M. Susi, 'The Definition of a "Structural Problem" in the Case-Law of the European Court of Human Rights since 2010', 55 German Yearbook of International Law (2012) p. 385 at p. 413; P. Leach et al., Responding to Systemic Human Rights Violations - An Analysis of Pilot Judgments of the European Court of Human Rights and their Impact at National Level (Intersentia 2010). 
TEU values to life in judicial proceedings against member states seemed to be a bit of a stretch. Today it is established jurisprudence which aims to protect the constitutional fundamentals of the European legal space. The values enshrined in Article 2 TEU apply to any member state action through mutual amplification with a specific provision of EU law. This includes the application of core EU rights beyond the limits of Article 51(1) CFR. The next step is developing the responsibilities of national courts as 'Union courts' under Article 2 TEU: a duty to interpret national law in conformity with Article 2 TEU values, a duty of referral when Article 2 TEU values are under threat and - as a last resort - the criminal liability of disobedient judges. These proposals seem to imply a massive extension of EU law's reach. However, it can hardly be stressed enough that, in order to safeguard the Union's federal balance, Article 2 TEU, as well as the corresponding responsibilities of national judges, are confined to extreme and exceptional situations.

Nobody knows whether these proposals will help government critics like Wojciech Sadurski or Adam Bodnar in the short term. Yet, it is evident that Union law is developing to better protect its very foundations, which includes helping its citizens in distress. There is no reason to despair. Europe has succeeded in stabilising the monetary union. This inspires hope about the union of values, not least because European resilience feeds here on a particularly potent source: the rejection of authoritarian government. 